\title{
Transition Metal Catalysis in Porphyrin Modifications
}

\author{
Alexei D. Averin, a,b Alexei A. Yakushev, and Irina P. Beletskaya ${ }^{\mathrm{a}, \mathrm{b} @}$ \\ ${ }^{a}$ M.V. Lomonosov Moscow State University, Department of Chemistry, 119991 Moscow, Russia \\ ${ }^{\mathrm{b}}$ A.N. Frumkin Institute of Physical Chemistry and Electrochemistry, 119991 Moscow, Russia \\ ${ }^{\circledR}$ Corresponding authorE-mail: beletska@org.chem.msu.ru
}

\begin{abstract}
A mini-review covers the results obtained by the authors in porphyrin modifications using $P d$ and Cu-catalyzed amination of halogenophenyl substituted porphyrins. Amination using primary and secondary linear and cyclic amines and diamines, formation of polymacrocyclic conjugates of aza- and diazacrown ethers and diazacrown ether-based cryptands with porphyrins are addressed. Synthesis of diporphyrin and triporphyrin systems via Pd-catalyzed amination and Cu-catalyzed "click" reactions are discussed.
\end{abstract}

Keywords: Porphyrins, macrocycles, catalysis, amination.

\section{Катализ переходными металлами в модификациях порфиринов}

\author{
А. А. Аверин, ${ }^{a}$ А. А. Якушев, ${ }^{b}$ И. П. Белецкая ${ }^{\mathrm{a},}$ \\ а Московский государственный университет им. М.В. Ломоносова, Химический факультет, 119991 Москва, Россия \\ ${ }^{\mathrm{b}}$ Институт физической химии и электрохимии им А.Н. Фрумкина, 119991 Москва, Россия \\ @E-mail: beletska@org.chem.msu.ru
}

\begin{abstract}
Данный мини-обзор посвящен результатам, полученным авторами при модификации порфиринов с использованием Pd- и Си-катализируемого аминирования галогенфенилзамещенных порфиринов. Рассматриваются аминирование с использованием первичных и вторичных линейных и ичиклических аминов и диаминов, образование полимакрочиклических конъюгатов порфиринов с аза-и диазакраун-эфирами и криптандами на основе диазакраун-эфиров. Обсуждается синтез ди- и трипорфириновых систем с использованием Рd-катализируемого аминирования и Си-катализируемьхх «клик-реакций».
\end{abstract}

Ключевые слова: Порфирины, макроциклы, катализ, аминирование.

\section{Introduction}

Modification of porphyrins using catalytic approaches is a modern and versatile tool for creating numerous derivatives of these unsaturated tetraazamacrocycles decorated with different functionalities, for the synthesis of sophisticated polymacrocyclic architectures comprising several porphyrin units (dyads and triads) or smart conjugates of porphyrins with other macrocyclic moieties. Hundreds of works have been already published dealing with various aspects of this topic, and corresponding information has been collected and organized in a comprehensive review in 2012. ${ }^{[1]} \mathrm{A}$ short outline of the catalytic transformations of porphyrins should start from the application of the reactions of C-C bond formation. Suzuki coupling is well documented since 1994 when this reaction was first applied by Zhou for the exocyclic transformation of the porphyrin core, ${ }^{[2]}$ porphyrin bearing halogen atoms ${ }^{[3]}$ and borylated porphyrins ${ }^{[4]}$ both find their applications in constructing new carbon-carbon bonds. The same is true for Sonogashira reaction which was first applied for the porphyrin modifications also in $1994,{ }^{[5]}$ and halogen-substituted porphyrins ${ }^{[6]}$ as well as porphyrins with acetylene moieties ${ }^{[7]}$ participate in the coupling. Heck and so-called "click" reactions were also among those which were successfully applied to the creation of new $\mathrm{C}-\mathrm{C}$ bonds in porphyrins, the first one applied to porphyrin modifications 
dates back to $1998^{[8]}$ while the second one began to be widely employed a decade later ${ }^{[9]}$ and is especially useful for the conjugation of porphyrins with various pharmacophores, sugars, oligonucleotides, fullerene, and moieties used for immobilization.

Catalytic formation of $\mathrm{C}-\mathrm{N}$ bonds according to Buchwald-Hartwig protocol, which is of especial value for our own research, till last time has been widely used for the introduction of quite simple substituents. In 2003 Chen and Zhang reported the first successful amination of monoand di-meso-halogeno substituted porphyrins and their $\mathrm{Zn}$ complexes with primary aliphatic and aromatic amines. ${ }^{[10]}$ In the same 2003 Suda studied Pd-catalyzed amination reactions of meso-bromosubstituted porphyrins using $\operatorname{Pd}(0)$ and $\mathrm{Pd}(\mathrm{II})$ catalysts with a variety of phosphine ligands. ${ }^{[11]}$ Lier claimed first catalytic amination of $\mathrm{Zn}$ complexes of mono- and di- $\beta$-halogenoporphyrins with aliphatic and aromatic amines in 2001. ${ }^{[12]}$ Zhang was the first who employed $\mathrm{Pd}(\mathrm{OAc})_{2}$ for di- and tetraamination of bis- and tetrakis(4-bromophenyl) susbstituted porphyrins. ${ }^{[13]}$ The year of 2003 was extremely fruitful for the pioneer works in the field of C-N bond formation in porphyrin series: Suda reported amidation of $\mathrm{Zn}$ and $\mathrm{Ni}$ meso-bromoporphyrin complexes with primary and secondary amides in the presence of $\mathrm{Pd}(\mathrm{OAc})_{2} / \mathrm{BINAP}^{[14]}$ Zhang modified this method applying $\mathrm{Pd}(\mathrm{OAc})_{2} /$ Xantphos system which allowed diamidation of di-meso-bromoporphyrins in high yields. [15] In 2001 amidation of $\beta$-bromoporphyrins using cyclic amides in the presence of $\mathrm{Pd}(\mathrm{dppf}) \mathrm{Cl}_{2} / \mathrm{dppf}$ was reported by Lier, ${ }^{[12]}$ and in 2007 Zhang proposed an universal approach for the amidation of mono- and dibromoporphyrins and their metal complexes using $\mathrm{Pd}_{2}(\mathrm{dba})_{3}$ or $\mathrm{Pd}(\mathrm{OAc})_{2}$ with Xantphos ligand. ${ }^{[16]}$

Alkoxy- and aryloxylation reactions of mono- and di-meso-bromophenylporphyrins catalyzed by $\mathrm{Pd}(\mathrm{OAc})_{2}$ or $\mathrm{Pd}_{2}(\mathrm{dba})_{3}$ with DPEphos or Xantphos were described in 2003 by same Zhang. ${ }^{[17]}$ In 2007 he was also the first who reported on successful synthesis of $\beta$-substituted alkoxyand aryloxyporphyrins using $\mathrm{Pd}_{2}(\mathrm{dba})_{3} / \mathrm{DPEphos}$ catalytic system and made chiral diporphyrin conjugates using catalytic $\mathrm{C}-\mathrm{O}$ bond formation. ${ }^{[18]}$ His group pioneered in the catalytic sulfanylation of mono- and di-mesobromoporphyrins employing the same catalytic system. ${ }^{[19]}$ Later on the catalytic synthesis of the first porphyrincontaining phosphineoxide was published, ${ }^{[20]}$ followed by the work of Guilard and Tsivadze in which di- and tetraphosphonylated porphyrins were synthesized using $\mathrm{Pd}(\mathrm{OAc})_{2} / \mathrm{PPh}_{3}$ catalytic system. ${ }^{[21]}$

As borylated porphyrins were found to be very useful building blocks for the synthesis of covalent porphyrin dimers and oligomers, their synthesis attracted much attention. Pinacol borane and bis(pinacol) borane are the most widely used reagents for this purpose. Therien ${ }^{[22]}$ proposed an earlier described Masuda protocol ${ }^{[23]}$ to be employed in the synthesis of mono- and di-meso-substituted porphyrins from pinacol borane and corresponding zinc (di)bromoporphyrinates using $\mathrm{Pd}\left(\mathrm{PPh}_{3}\right)_{2} \mathrm{Cl}_{2}$, this approach was further developed by Zhang and Suslik. ${ }^{[24]} \mathrm{Pd}(\mathrm{dppf})$ $\mathrm{Cl}_{2}$ was helpful for the borylation of 2-bromosubstituted porphyrin, ${ }^{[25]}$ and the methodology was spread for the synthesis of tetra-meso-borylated compounds. ${ }^{[26]}$
An important aspect of the catalytic transformations of porphyrins is the synthesis of polyporphyrin species. meso-meso-Conjugated porphyrin dimer ${ }^{[27]}$ and trimer ${ }^{[28]}$ without a linker were synthesized using Suzuki coupling, the same approach was used for the synthesis of dimers with face-to-face organized porphyrin units attached to aromatic linkers, ${ }^{[29]}$ as well as for a linear trimer. ${ }^{[30]}$ Stille coupling was used for the synthesis of various porphyrin dimers, ${ }^{[31,32]}$ especially for the derivatives with long polyene systems. ${ }^{[33]}$ Heck and Sonogashira reactions are also widely employed for the synthesis of bisporphyrin compounds with different linkers including acetylenic fragments, ${ }^{\left[{ }^{[3]}\right.}$ the latter approach was helpful in the synthesis of porphyrin trimers as well. [35] Catalytic amination and alkoxylation reactions were successfully applied to the synthesis of porphyrin dimers and trimers. ${ }^{[36]} \mathrm{Cu}(\mathrm{I})$-catalyzed 1,3-dipolar cycloaddition reactions can be also used for the synthesis of porphyrin dyads with 1,2,3-triazole linkers. ${ }^{[37]}$ Above-mentioned catalytic reactions were widely used also for creating bisand trisporphyrin systems with $\beta-\beta$ and $\beta$-meso conjugation, and para-phenylene linkers were the most widely used in all these processes including metathesis reactions. ${ }^{[38]}$

A special interest is attracted by the catalytic reactions leading to macropolycyclic compounds comprising porphyrin structural units. For example, Heck reaction was used for the synthesis of the macrotricycle in which two crown ethers are fused with the central porphyrin moiety. ${ }^{[39]}$ Suzuki coupling allowed the synthesis of pentamacrocycle with three porphyrin units, ${ }^{[40]}$ while the metathesis reaction, which used the template effect of tetra-meso-pyridylporphyrin, allowed the synthesis of a huge tetraporphyrin macrocycle. ${ }^{[41]}$ All these data clearly demonstrate efficiency and versatility of the catalytic approaches in the porphyrin transformations.

\section{Catalytic Amination of meso-(Bromophenyl) Substituted Porphyrins}

Our own contribution to the field of catalytic transformation of porphyrins deals mainly with the Pd-catalyzed amination reactions and the first works published in $2008^{[42,43]}$ considered the reactions of $\beta$-octaalkylated mono- and di-meso-(4-bromophenyl)porphyrins $\mathbf{1}$ and $\mathbf{2}$ with a variety of cyclic amines, especially hydroxypiperidines, which are the simplest analogues of polyhydroxylated piperidine alkaloids used as HIV replication inhibitors. The reactions employed $\mathrm{Pd}(\mathrm{OAc})_{2}$ as the source of palladium, several electron-donor phosphines ligands were checked, and among them biphenyl-based ligands L1 and L2 and ferrocene-derived ligand $\mathbf{L} \mathbf{3}$ were found to be most efficient providing yields of monoaminated derivatives $\mathbf{3}$ up to $83 \%$ and yields of diaminated derivatives 4 up to $82 \%$ (Scheme 1). In the case of di(bromophenyl)porphyrin 2 the formation of side products of monoamination with the reduction of $\mathrm{C}$-Br bond was noted, and in the case of monobromide $\mathbf{1}$ the formation of meso-phenylporphyrin also due to the catalytic reduction was observed with several amines.

Our further development of the Pd-catalyzed amination of meso-(4-bromophenyl)porphyrin was focused on the 

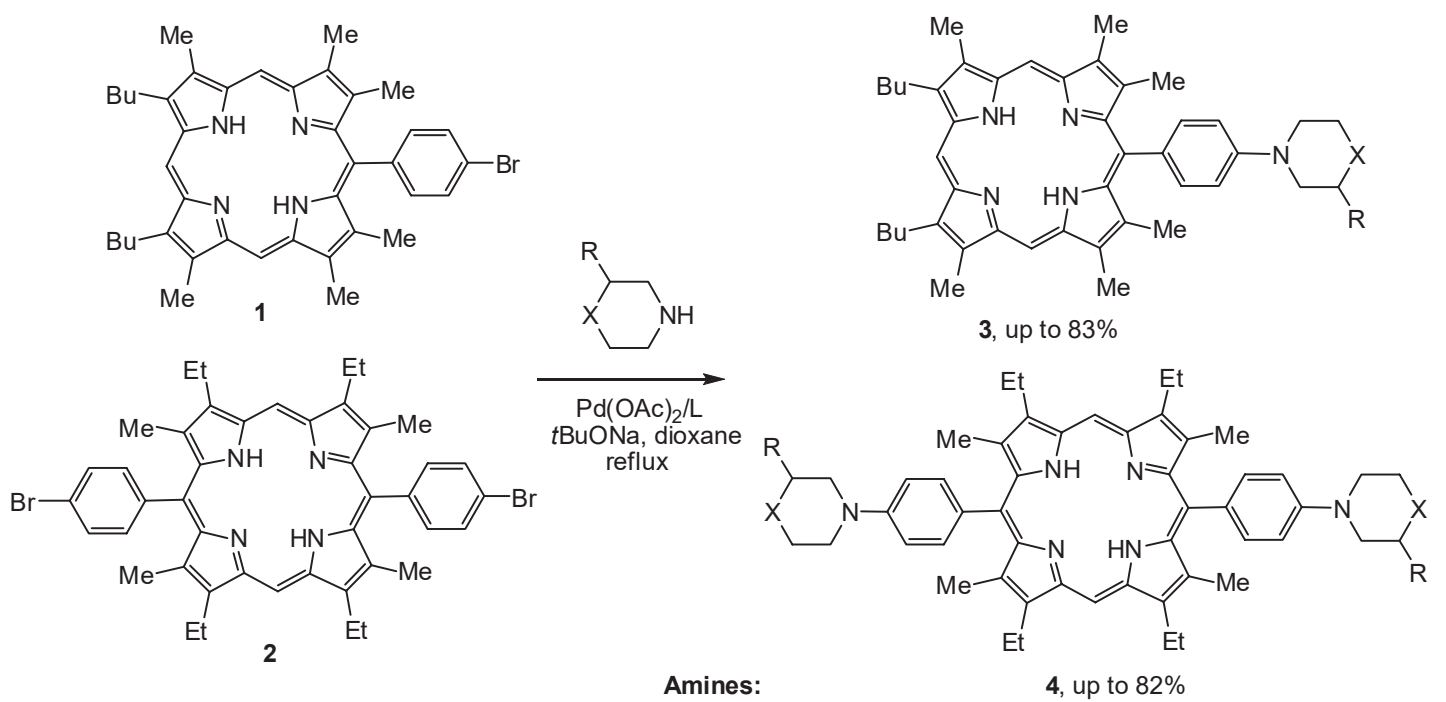

Amines:
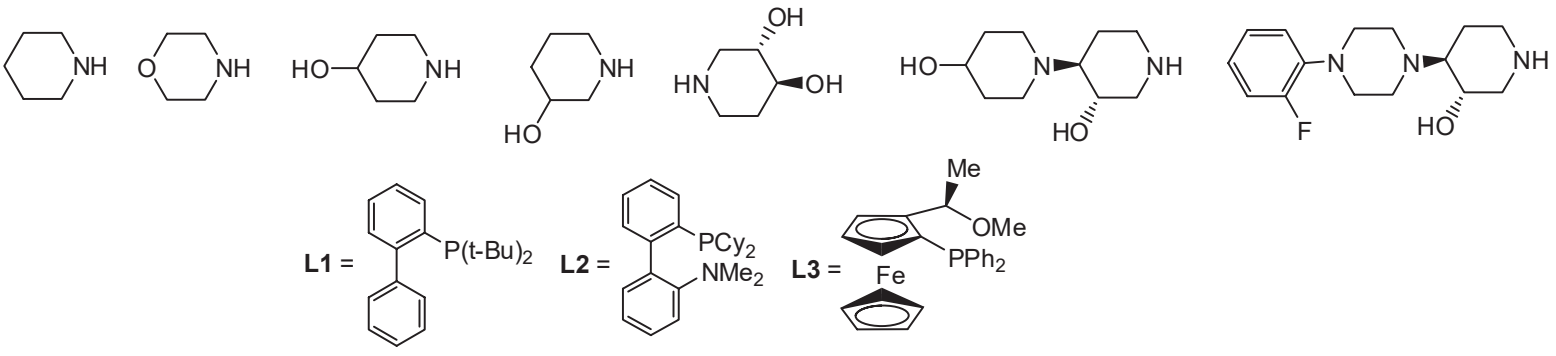

Scheme 1.

reactions of its $\mathrm{Zn}$ (II) complex $\mathbf{5}$ with various primary and secondary amines using $\mathrm{Pd}(\mathrm{dba})_{2}$ as a source of palladium as it was shown to be advantageous over Pd(II) acetate in many other catalytic amination reactions. The efficiency of two most universal phosphine ligands, i.e. DavePhos (L2) and BINAP (L4) were compared in the reactions with ethane1,2-diamine and its $N$-methyl derivatives, piperazine, diaza18-crown-6 ether and $N, N^{\prime}, N$ '”-triBOCcyclen (Scheme 2). ${ }^{[44,45]}$ The reactions were carried out using 1.5 equiv. of macrocyclic polyamines and 5 equiv. of other diamines to prevent $N, N^{\prime}$-diarylation. As a result, the reaction with both isomers of dimethylethane-1,2-diamine, piperazine and even much more problematic 1-aza-15-crown-5 ether gave excellent yields of the amination products $\mathbf{6}, 7, \mathbf{9}$, $10(88-95 \%)$ while the reaction with the simplest ethane1,2-diamine proceeded with difficulties, possibly due to unfavorable chelation of Pd by this diamine. The reactions with diazacrown ether and triBOC cyclen afforded quite reasonable yields of the products $\mathbf{1 1}$ and $\mathbf{1 2}$ (49 and $38 \%$, respectively), especially comparing with our own results dealing with the $\operatorname{Pd}(0)$-catalyzed arylation of these compounds using more simple aryl halides which provided $32-45 \%$ yields of corresponding $N$-aryl derivatives. ${ }^{[46,47]}$

The next step in the application of Buchwald-Hartwig amination for porphyrins modifications was done using 5,15-di(4-bromophenyl)porphyrin $\mathbf{1 3}$ (Scheme 3). To promote diamination process, the reactions were carried out using 10 equiv. of diamines in the presence of $\mathrm{Pd}(\mathrm{dba})_{2} /$ BINAP (8/16 mol\%). As a result, diamino derivative 14 was obtained in $50 \%$ yield from the unsymmetrical $N, N$ dimethylethane-1,2-diamine with a primary amino group together with the product of monoamination and reduction of one $\mathrm{C}-\mathrm{Br}$ bond (compound 15, $32 \%$ yield). However, the reaction with the secondary diamine piperazine was less successful and corresponding product of diamination $\mathbf{1 6}$ was isolated only in $19 \%$ yield while compound $\mathbf{1 7}$ with one new $\mathrm{C}-\mathrm{N}$ bond was obtained in a two-fold higher yield. The reaction with 1-aza-15-crown-5 ether and diaza18-crown-6 ether were conducted using 3 equiv. of this cyclic diamines and $\operatorname{Pd}(\mathrm{dba})_{2} /$ BINAP catalytic system providing only insignificant amount of the corresponding bis(azacrown) derivatives $\mathbf{1 8}$ and 20. The application of DavePhos was helpful and it afforded good yields of the target compounds 18 and 20 (64 and $63 \%$, respectively), while the monoamination products $\mathbf{1 9}$ and $\mathbf{2 1}$ were also obtained in 30 and $36 \%$ yields. However, the same catalytic system did not allow the formation of biscyclen product in the reaction with 3 equiv. of triBOCcyclen, but rather gave monocyclen derivative 22 in 50\% yield. Almost in all cases the formation of 5,15-diphenylporphyrin, the product of the double reduction of two C-Br bonds, was observed.

Coordination properties of the compounds $\mathbf{1 0}$ and $\mathbf{1 8}$ towards $\mathrm{Na}(\mathrm{I})$ and $\mathrm{K}(\mathrm{I})$ cations were studied using UV-vis spectroscopy ${ }^{[45]}$ It was found that coordination of these ligands with sodium cation provided complexes of $\mathbf{1 0} * \mathrm{Na}(\mathrm{I})$ and $18 * 2 \mathrm{Na}(\mathrm{I})$ compositions, while a bigger potassium cation formed complexes of $2(\mathbf{1 0}) * \mathrm{~K}(\mathrm{I})$ and $2(\mathbf{1 8}) * 2 \mathrm{~K}(\mathrm{I})$ compositions, respectively.

Tetrakis-meso-(4-bromophenyl)porphyrins 22 and 23 with expanded $\pi$-systems were introduced in the amination reactions using $\mathrm{Pd}(\mathrm{dba})_{2} / \mathbf{L} 2$ or $\mathrm{Pd}(\mathrm{dba})_{2} / \mathbf{L} \mathbf{4}$ catalytic systems (Scheme 4). ${ }^{[48]}$ The reactions were run using 6 equiv. of 

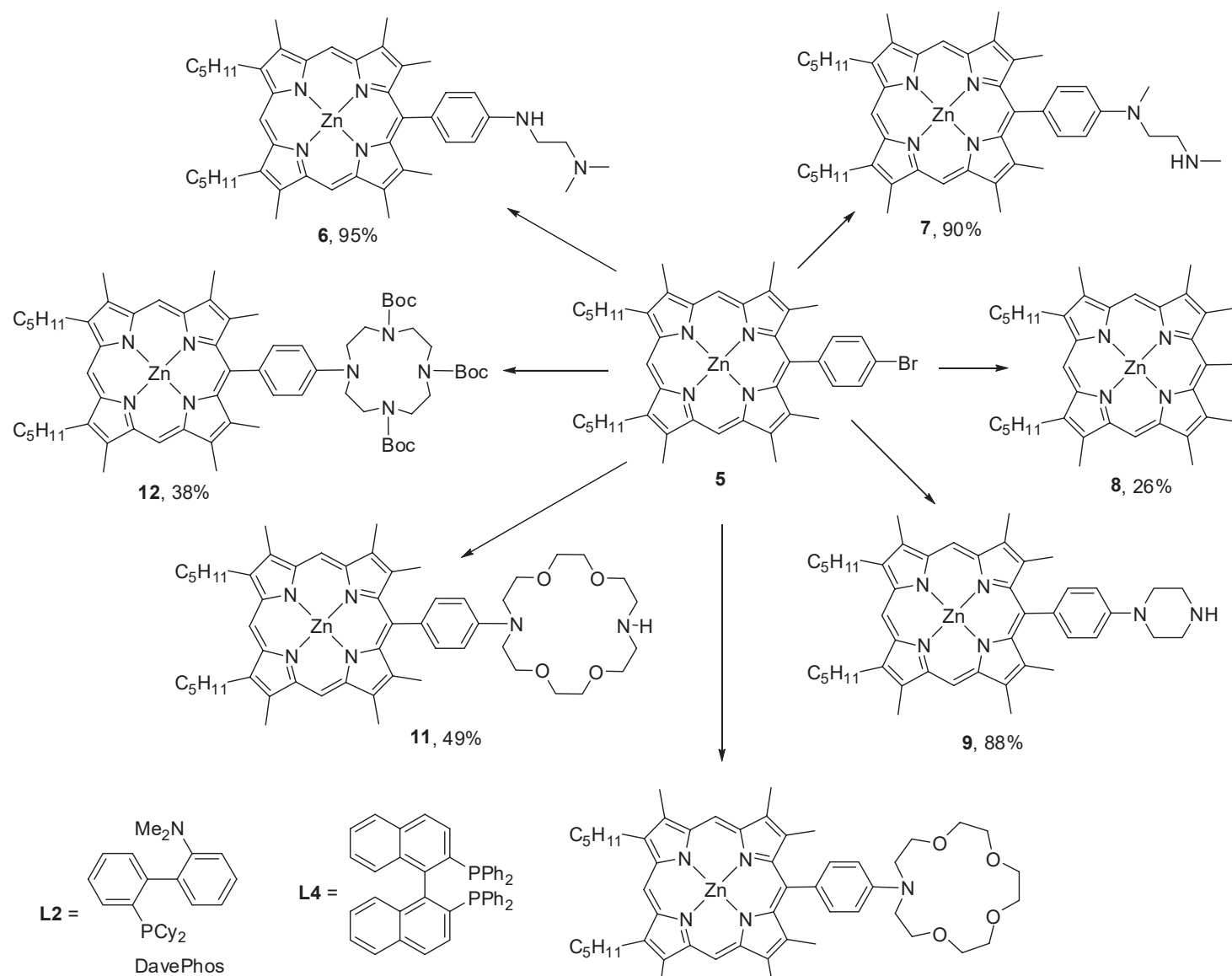

(rac)-BINAP

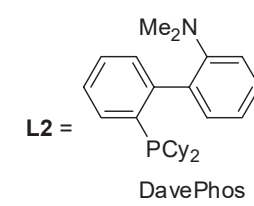

$7,90 \%$

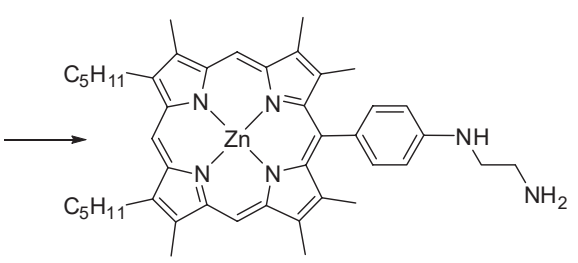

$8,26 \%$

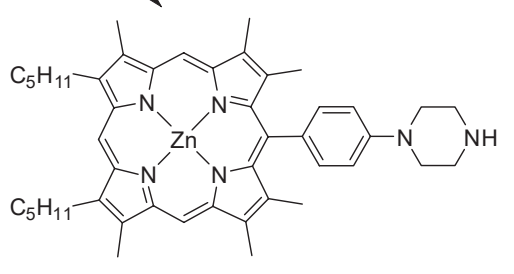

9, $88 \%$

$11,49 \%$

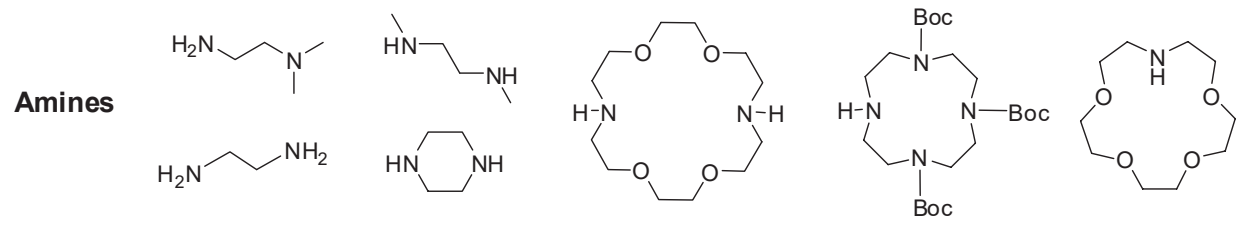

Scheme 2.

amines differing by the nature of the amino groups (primary aliphatic, primary aromatic, secondary aliphatic, dioxadiamine with two primary aliphatic amino groups). Generally, the reactions with the derivatives of tetrabenzoporhyrins provided better yields of the products of tetraamination than the derivatives of tetranaphthoporphyrins, however in the case of morpholine a higher yield in the reaction with tetranaphthoporphyrin $\mathbf{2 3}$ was achieved by changing BINAP for DavePhos. The reaction of tetrabenzoporphyrin 22 with 6 equiv. of 1-aza-18-crown-6 ether gave a mixture of two products: target pentamacrocycle $\mathbf{3 1}$ and tetramacrocycle 32 produced by the catalytic reduction of $\mathrm{C}-\mathrm{Br}$ bond. This reaction could be carried out only in the presence of $\operatorname{Pd}(\mathrm{dba})_{2} / \mathbf{L} 2$ catalytic system.

The application of a much cheaper copper instead of expensive palladium in the catalytic reactions is a serious challenge of modern synthetic organic chemistry. We tried it in the modification of porphyrins with one and two (oxa)diamine podands. For this purpose, we compared the possibilities of $\mathrm{Pd}(0)$ and $\mathrm{Cu}(\mathrm{I})$-catalyzed amination of meso-(halogenophenyl)porphyrins with trioxadiamine
(Scheme 5), in the experiment with palladium catalysis we used bromophenyl derivative $\mathbf{5}$ while for copper catalysis an iodophenyl substituted porphyrin $\mathbf{3 3}$ was applied. The yields of the corresponding trioxadiamine derivatives $\mathbf{3 4}$ and 36 were rather low, however, in the reaction with a simple propane-1,3-diamine the copper-catalyzed reaction was quite successful and provided $50 \%$ conversion of the starting porphyrinate $\mathbf{3 3}$ into the target product $35 .{ }^{[49]}$ It should be noted that only metallated porphyrins can participate in the copper-catalyzed couplings unlike in palladium-catalyzed reactions, this fact can be explained by the formation of stable complexes of free porphyrins with copper eliminating it from the catalytic cycle.

$\operatorname{Pd}(0)$ and $\mathrm{Cu}(\mathrm{I})$-catalyzed diamination of di-meso(bromophenyl)porphyrins 13, 37 and 38 clearly demonstrated that palladium catalysis was advantageous over copper catalysis as the first approach allowed to synthesize porphyrin bis(diamino) derivatives 39, 41 in reasonable yields while in the presence of copper-based catalytic systems target compounds were observed only in the reaction mixtures in insignificant amounts. 

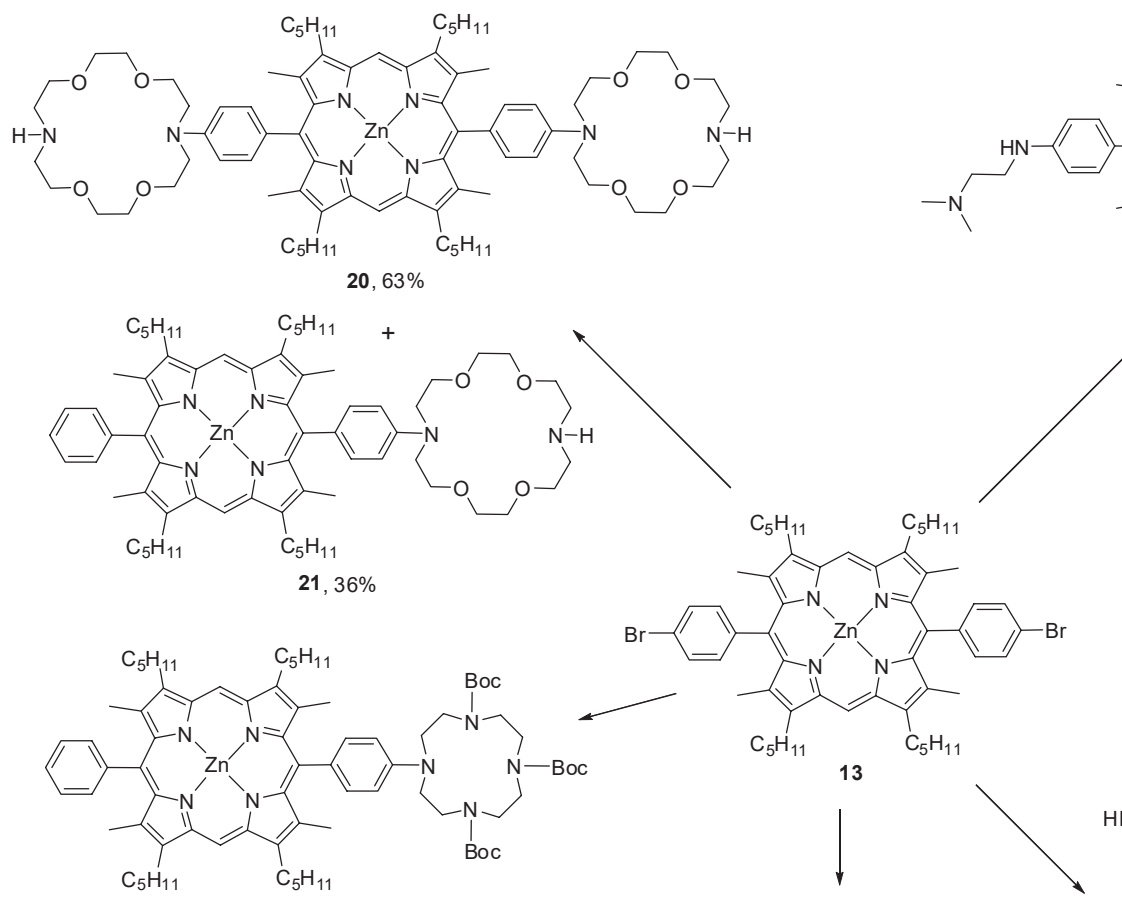

$22,50 \%$

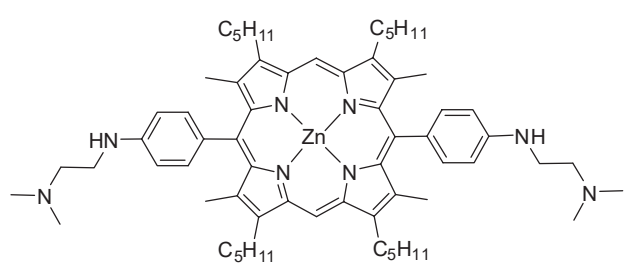

$14,50 \%$

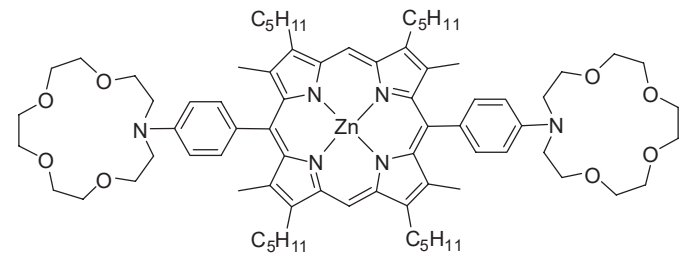

$18,64 \%$
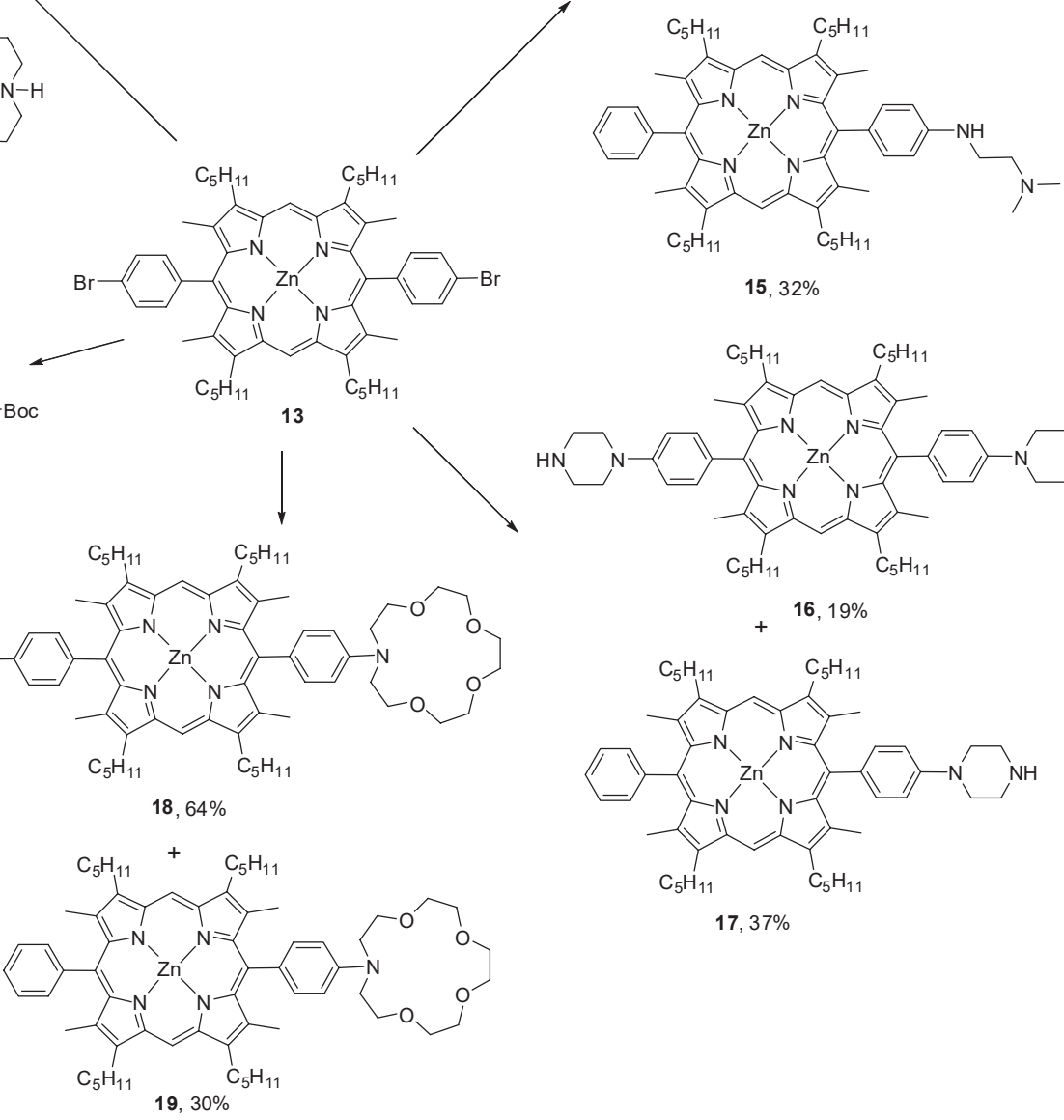

$15,32 \%$

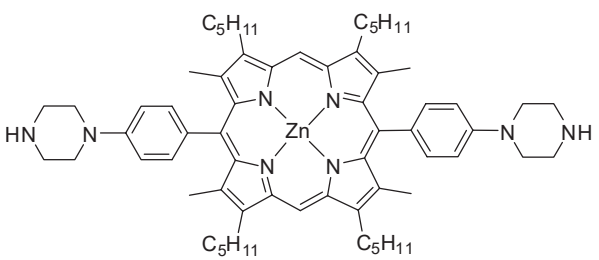

$+\quad 16,19 \%$

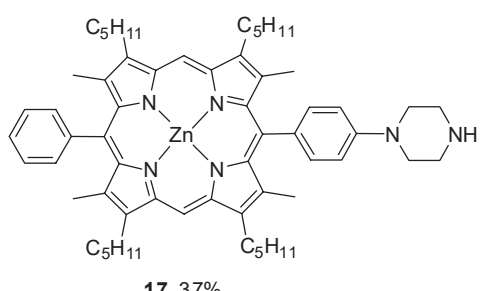

$17,37 \%$

Scheme 3.

Synthesis of azacrown-porphyrin conjugates with diamine linkers can be achieved by reacting diamino derivative of azacrown ethers with mono- and di-meso(bromophenyl)porphyrins in the presence of the palladium catalyst. Compounds 44 and 45 were obtained also using $\operatorname{Pd}(0)$ or $\mathrm{Cu}(\mathrm{I})$-catalyzed amination reactions. ${ }^{[50]}$ We have found out that mono(bromophenyl)porphyrin must be employed only as its $\mathrm{Zn}(\mathrm{II})$ complex 46 while di(bromophenyl)porphyrin can be introduced in the coupling equally as its $\mathrm{Zn}$ (II) complex 13 and free base 37 (Scheme 6). Corresponding bis- and trismacrocycles $47-49$ were isolated in $15-20 \%$ yields. ${ }^{[1]}$ It was also shown that alternative synthesis using diamino derivatives of porphyrin and bromobenzyl substituted azacrown ethers led exclusively to the catalytic reduction of $\mathrm{C}$-Br bond and no conjugates could be obtained. UV-vis and fluorescence spectra of conjugates 47-49 were studied in the presence of 18 metal cations including alkali and alkali earth metals, widely spread transition metals and heavy metals known to be most important pollutants of water. Trismacrocycle $\mathbf{4 8}$ was found to be a sensitive fluorescent chemosensor for $\mathrm{Cu}$ (II) cations by full emission quenching, and the presence of other metals tested did not interfere the detection of copper.

\section{Synthesis of Porphyrin Dyads and Triads Using Pd(0)-Catalyzed Amination}

Our own contribution to the field of catalytic transformation of porphyrins deals mainly with the synthesis of polymacrocyclic compounds comprising one or several porphyrin structural units, the latter are known as porphyrin dyads and triads in which porphyrin macrocycles are combined via various linkers. We have shown above that starting from $\mathrm{Zn}$ (II) meso-(4-bromophenyl)porphyrinate $\mathbf{5}$ we obtained a series of diamino derivatives (see Scheme 2). Some of them, namely porphyrins 7-9 and $\mathbf{1 1}$ were introduced in the catalytic arylation using either the same $\mathrm{Zn}$ (II) porphyrinate $\mathbf{5}$ or analogous $\mathrm{Sn}(\mathrm{IV})$ and $\mathrm{Ni}$ (II) porphyrinates 50 and 51 (Scheme 7), as a result novel heterometallic porphyrin dyads 52-55 and biszinc porphyrin dyad 56 


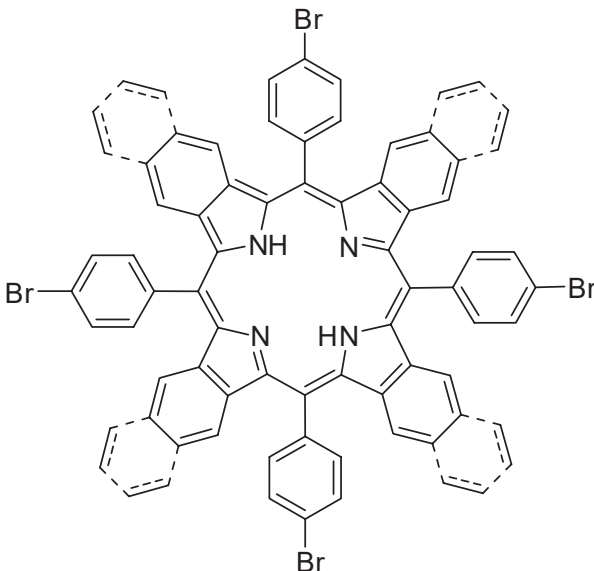

20, tetrabenzoporphyrin 21, tetranaphthoporphyrin

Products: $\quad R R ' N=N$

22 (tetrabenzo), 88\% 23 (tetranaphtho), 44\%
$\mathrm{H}_{2} \mathrm{~N} \curvearrowright \overbrace{\mathrm{O}} \sim \mathrm{NH}$

24 (tetrabenzo), 44\%

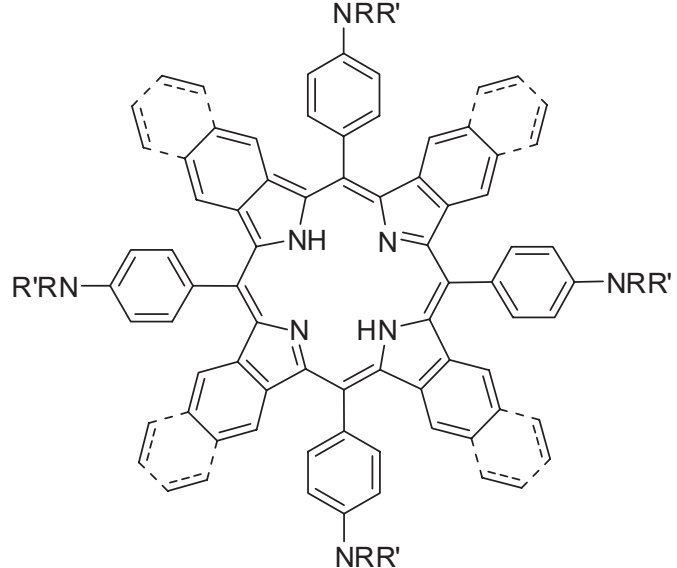<smiles>Cc1ccc(N)cc1</smiles>

$\mathrm{NH}$<smiles>C1COCCN1</smiles>

27 (tetrabenzo), 30\% 28 (tetranaphtho), 82\%

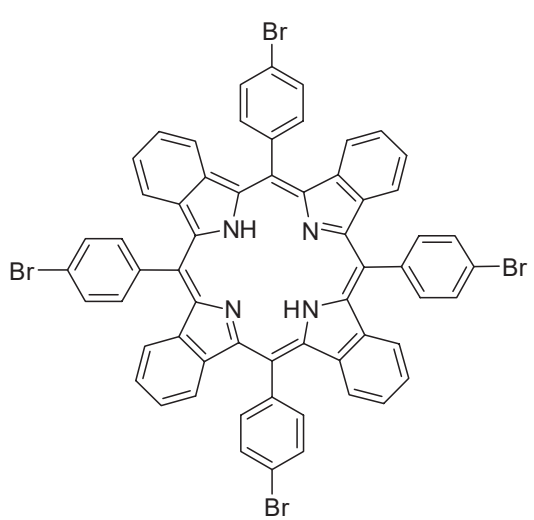

20

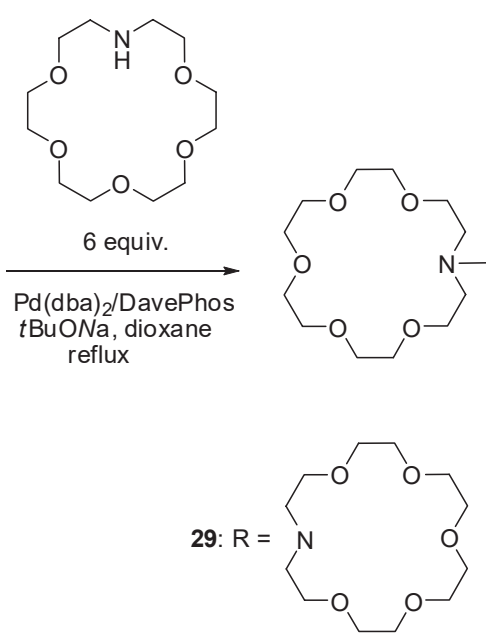

30: $\mathrm{R}=\mathrm{H}$
25 (tetrabenzo), 69\% 26 (tetranaphtho), 39\%

L - BINAP, DavePhos

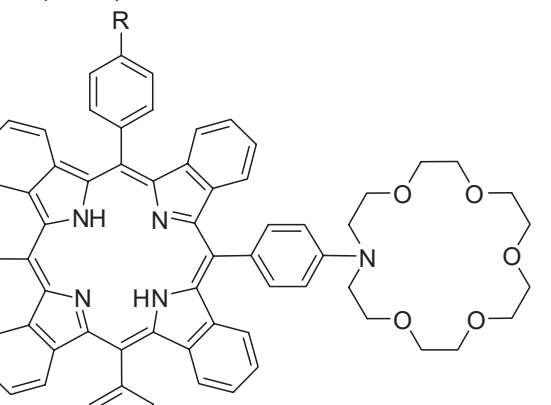

\section{Scheme 4.}

were synthesized in yields $22-56 \%{ }^{[52]} \mathrm{Pd}(\mathrm{dba})_{2} /$ BINAP catalytic system was used for the synthesis of the majority of compounds while $\mathrm{Pd}(\mathrm{dba})_{2} /$ DavePhos was employed in the synthesis of trismacrocycles with diazacrown ether linker. Coordination properties of the tweezer $\mathbf{5 2}$ with $\mathrm{Cu}(\mathrm{II})$ cations and supramolecular organization of trismacrocycle 55 using DABCO were studied.

Another approach to bisporphyrin compounds utilizes the possibility of the catalytic $N, N$-diarylation of the primary amino group. Using this approach, diamino derivative $\mathbf{6}$ was introduced in the reaction with $\mathrm{Sn}(\mathrm{IV})$ porphyrinate 50 in the presence of $\mathrm{Pd}(\mathrm{dba})_{2} /$ DavePhos catalytic system, and the target porphyrin dyad $\mathbf{5 7}$ was isolated in $18 \%$ yield (Scheme 7). This compound is notable for its diphenylamino linker between two porphyrin units.

Above-mentioned successful synthesis of 5,15-bis(diamino) derivatives of porphyrins (see Scheme 3) opens a way for more complex compounds, i.e. porphyrin triads with diamino linkers. Bis(piperazine) derivative $\mathbf{1 6}$ was introduced in the reaction with zinc porphyrinate $\mathbf{5}$ catalyzed by $\mathrm{Pd}(\mathrm{dba})_{2} /$ DavePhos and the desired triad $\mathbf{5 8}$ was obtained in an excellent $75 \%$ yield (Scheme 8 ). ${ }^{[33]}$ We verified the importance of the use of $\mathrm{Zn}(\mathrm{II})$ complex: the same reaction with a free porphyrin base afforded only $6 \%$ yield of the corresponding triad. Pentamacrocyclic porphyrin triad $\mathbf{5 9}$ utilizing diazacrown ethers as linkers was obtained via a similar reaction employing bis(azacrown) derivative 20 (Scheme 8). It is to be noted that previously, in the course of the synthesis of bis(diamino) derivatives of porphyrins, we noted the formation of porphyrin dyads as by-products when the excess of diamines was insufficient to prevent their $N, N^{\prime}$-diarylation.

The synthesis of the porphyrin triad with a diphenylamino linker can be accomplished using the reaction of 2 equiv. of $\mathrm{Zn}$ (II) porphyrinate 5 with another compound, 5,15-di(4-aminophenyl) substituted porphyrin $\mathbf{6 0}$ (Scheme 9). ${ }^{[53]}$ Corresponding triad $\mathbf{6 1}$ was obtained in $21 \%$ yield and added to a list of polyporphyrin compounds synthesized via Buchwald-Hartwig amination reactions. 


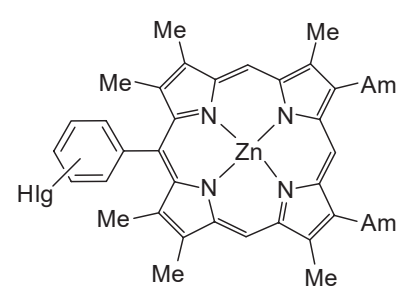

$\mathrm{Hlg}=p-\mathrm{Br}(\mathbf{5}), m-\mathrm{I}(\mathbf{3 1})$

$$
\begin{aligned}
& \begin{array}{l}
\mathrm{H} \\
\mathrm{X}=\mathrm{CH}_{2}
\end{array} \\
& \text { a) } \mathrm{Clg}=\mathrm{Br} \mathrm{CH}_{2}\left[\begin{array}{l}
\mathrm{Pd}(\mathrm{dba})_{2} / \mathrm{BINAP} \\
\text { tBuONa, dioxane }
\end{array}\right. \\
& \text { b) } \mathrm{Hlg}=\mathrm{I} \quad \mathrm{Cul} / \mathrm{L} \text { 5/DMF, } \mathrm{Cs}_{2} \mathrm{CO}_{3}
\end{aligned}
$$

L5 $=$<smiles>CC(C)C(=O)C1CCCCC1=O</smiles>

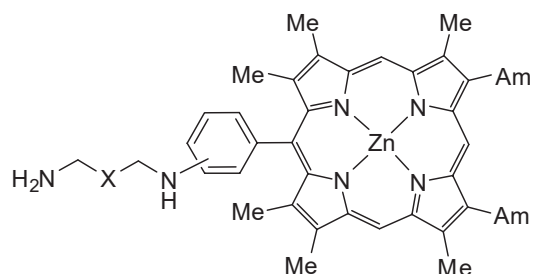

32: $p-\mathrm{NH}, \mathrm{X}=\mathrm{CH}_{2} \mathrm{CH}_{2}\left[\mathrm{OCH}_{2} \mathrm{CH}_{2}\right]_{2} \mathrm{OCH}_{2} \mathrm{CH}_{2}, 16 \%$ (via Pd catalysis) 33: $m-\mathrm{NH}, \mathrm{X}=\mathrm{CH}_{2}, 50 \%$ (via Cu catalysis)

34: $m-\mathrm{NH}, \mathrm{X}=\mathrm{CH}_{2} \mathrm{CH}_{2}\left[\mathrm{OCH}_{2} \mathrm{CH}_{2}\right]_{2} \mathrm{OCH}_{2} \mathrm{CH}_{2}, 10 \%$ (via Cu catalysis)

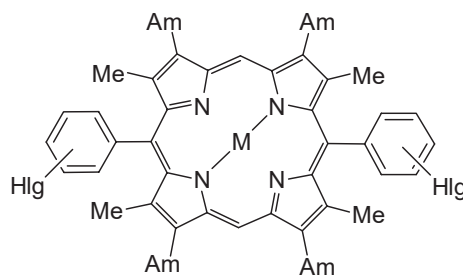

$\mathrm{Hlg}=p-\mathrm{Br}, \mathrm{M}=2 \mathrm{H}(35)$ $p-B r, M=Z n(13)$ $m-\mathrm{Br}, \mathrm{M}=2 \mathrm{H}(36)$

$$
\begin{aligned}
& \widehat{\mathrm{H}_{2} \mathrm{~N}} \widehat{\widehat{X}-6 \text { equiv. }} \widehat{\mathrm{NH}_{2}} \\
& \begin{array}{l}
\mathrm{X}=\mathrm{CH}_{2} \\
\mathrm{X}=\mathrm{CH}_{2} \mathrm{CH}_{2}\left[\mathrm{OCH}_{2} \mathrm{CH}_{2}\right]_{2} \mathrm{OCH}_{2} \mathrm{CH}_{2}
\end{array}
\end{aligned}
$$

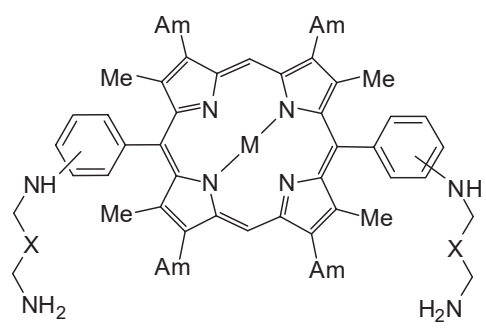

$\mathrm{H}_{2} \mathrm{~N}$

37: $p-\mathrm{NH}, \mathrm{M}=2 \mathrm{H}, \mathrm{X}=\mathrm{CH}_{2}, 49 \%$ (via Pd catalysis)

38: $p-\mathrm{NH}, \mathrm{M}=\mathrm{Zn}, \mathrm{X}=\mathrm{CH}_{2}$, observed in the reaction mixture (via Cu catalysis)

39: $m-\mathrm{NH}, \mathrm{M}=2 \mathrm{H}, \mathrm{X}=\mathrm{CH}_{2} \mathrm{CH}_{2}\left[\mathrm{OCH}_{2} \mathrm{CH}_{2}\right]_{2} \mathrm{OCH}_{2} \mathrm{CH}_{2}, 15 \%$ (via Pd catalysis)

40: $m-\mathrm{NH}, \mathrm{M}=2 \mathrm{H}, \mathrm{X}=\mathrm{CH}_{2} \mathrm{CH}_{2} \mathrm{O}\left(\mathrm{CH}_{2}\right)_{4} \mathrm{OCH}_{2} \mathrm{CH}_{2} 30 \%$ (via Pd catalysis)

41: $m-\mathrm{NH}, \mathrm{M}=\mathrm{Zn}, \mathrm{X}=\mathrm{CH}_{2} \mathrm{CH}_{2}\left[\mathrm{OCH}_{2} \mathrm{CH}_{2}\right]_{2} \mathrm{OCH}_{2} \mathrm{CH}_{2}$, traces (via Cu catalysis)

Scheme 5.

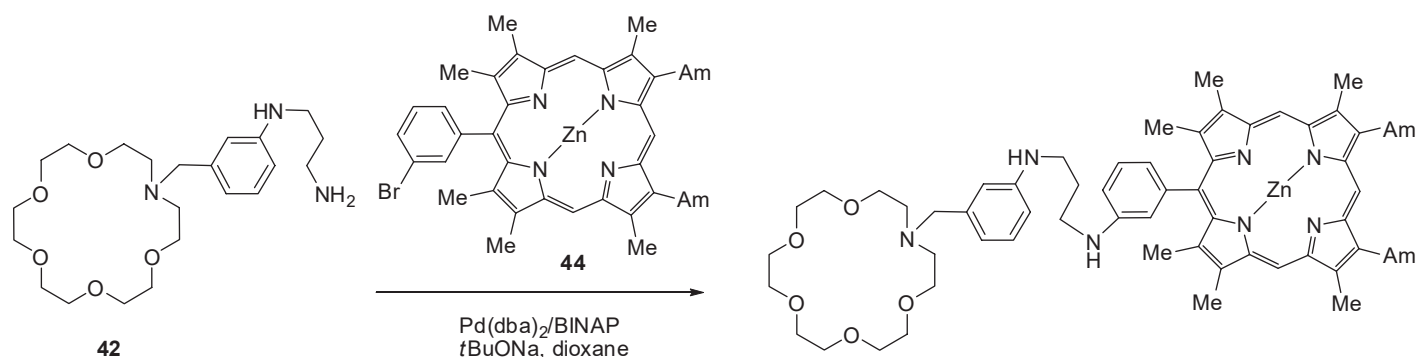

45, $15 \%$
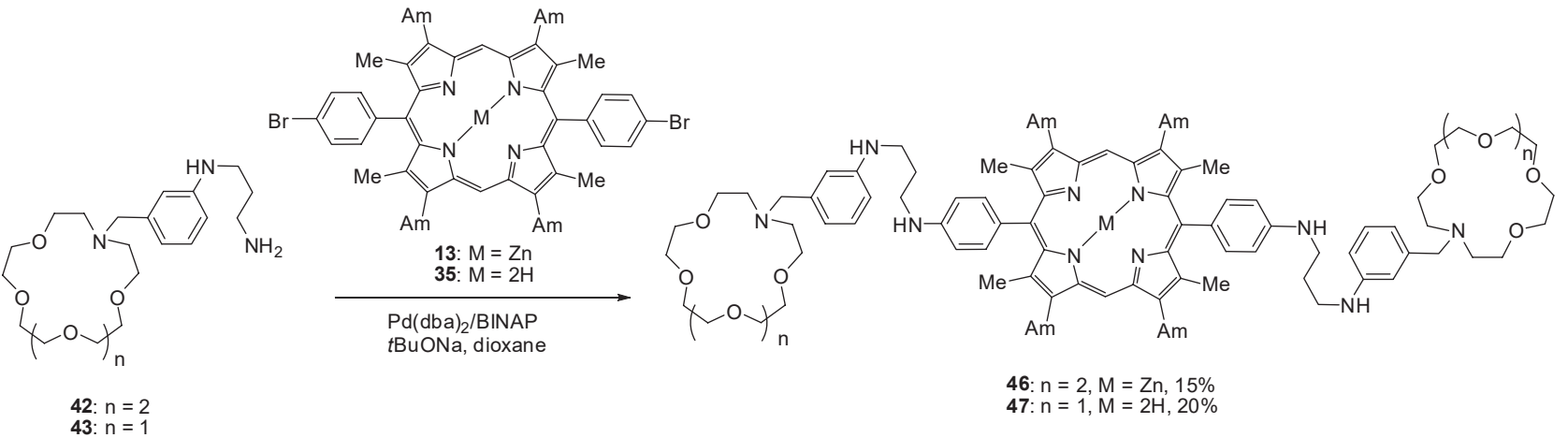

46: $n=2, M=Z n, 15 \%$
$47: n=1, M=2 H, 20 \%$

Scheme 6

$\mathrm{Cu}(\mathrm{I})$-catalyzed 1,3-dipolar cycloaddition reactions were successfully used for the synthesis of porphyrin triads containing 1,2,3-triazole linkers. For this purpose two combinations of starting compounds were tried. The first reaction scheme employed 5,15-bis(ethynylphenyl) derivative of porphyrin $\mathbf{6 2}$ with 2 equiv. of meso-(4-azidophenyl) substituted porphyrin 63 (Scheme 10). Reaction conditions were adjusted to provide the best yield of the target trisporphyrin compound 64, the best were found to be CuI/DIPEA in THF-MeCN solution which gave $68 \%$ yield of this triad, and a classical system $\left(\mathrm{CuSO}_{4} /\right.$ sodium ascorbate in DMF) to provide slightly lower yield $60 \% .{ }^{[54]}$ According to the second reaction route, 5,15-bis(4-azidophenyl) substituted porphyrin 65 was coupled with 2 equiv. of meso-(4-ethynyl- 


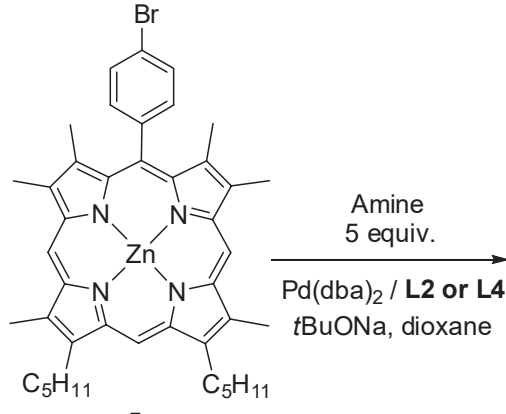

Amines:<smiles>CNCCNC</smiles><smiles>C1CCOCCOCCNCCOCCOC1</smiles>

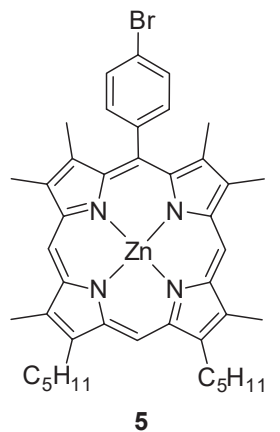

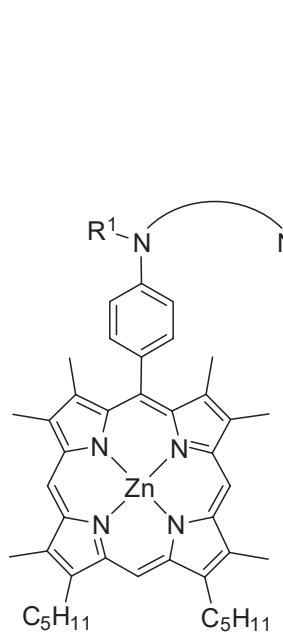

$7-9,11$

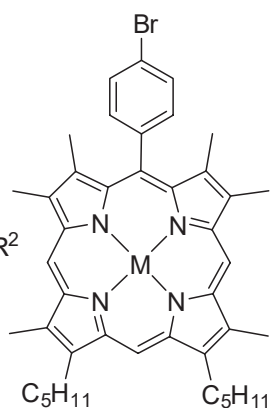

5: $M=Z n$

48: $\mathrm{M}=\mathrm{Sn}(\mathrm{OH})_{2}$

49: $\mathrm{M}=\mathrm{Ni}$

$\mathrm{Pd}(\mathrm{dba})_{2} / \mathrm{L} 2$ or L4

tBuONa, dioxane

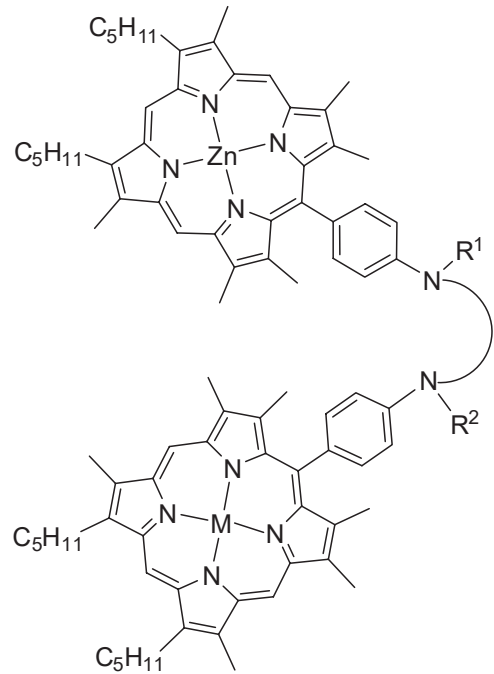

50 :

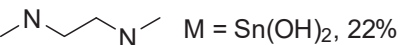

51: $\mathrm{HN} \smile ح_{\mathrm{NH}} \mathrm{M}=\mathrm{Sn}(\mathrm{OH}) 2,28 \%$

52:

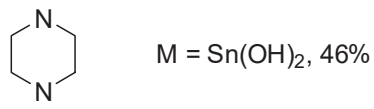

53: diazacrown, $\mathrm{M}=\mathrm{Ni}, 50 \%$

54: diazacrown, $\mathrm{M}=\mathrm{Zn}, 56 \%$

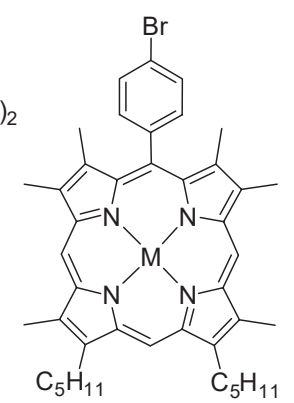
$\mathrm{C}_{5} \mathrm{H}_{11}$

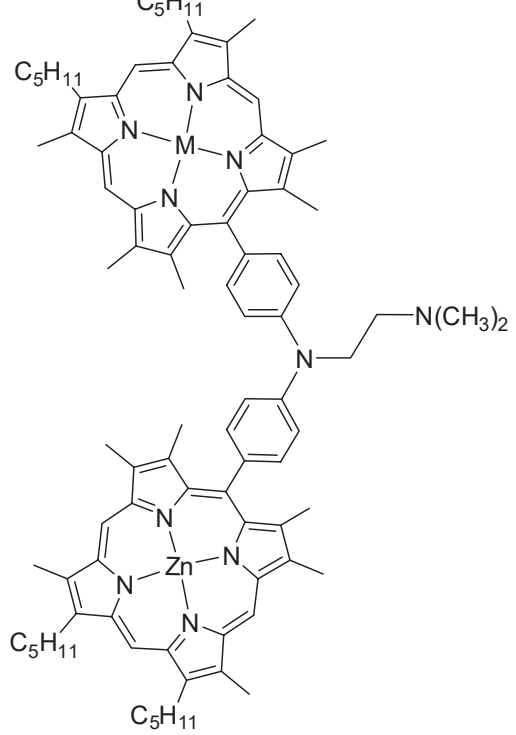

55: $\mathrm{M}=\mathrm{Sn}(\mathrm{OH})_{2}, 18 \%$

Scheme 7.

phenyl)porphyrin 66 in the presence of CuI/DIPEA in THF$\mathrm{MeCN}$ (Scheme 11) and it produced an isomeric porphyrin triad 67 in a high $70 \%$ yield. It was also shown that a simpler porphyrin dyad could be easily synthesized by reacting porphyrins 63 and 66 under the same conditions.

Porphyrin triad of a star shape was successfully synthesized using the similar approach: 1,3,5-tri(ethynyl) benzene was reacted with 3 equiv. of meso-(4-azidophenyl) substituted porphyrin $\mathbf{6 3}$ and the target triad $\mathbf{6 8}$ was isolated in $30 \%$ yield (Scheme 12). ${ }^{[55]}$ It is to be mentioned that only zinc porphyrinates but not free porphyrin bases can participate in these reactions as the latter easily coordinate copper eliminating it from the catalytic cycle.

\section{Catalytic Modification of Macrocyclic Compounds with Porphyrin Units}

Porphyrin moiety possesses valuable optical properties as a strong chromophore and fluorophore group. Thus it was interesting to modify some macrocycles and macrobicycles by porphyrin units for their further examination 


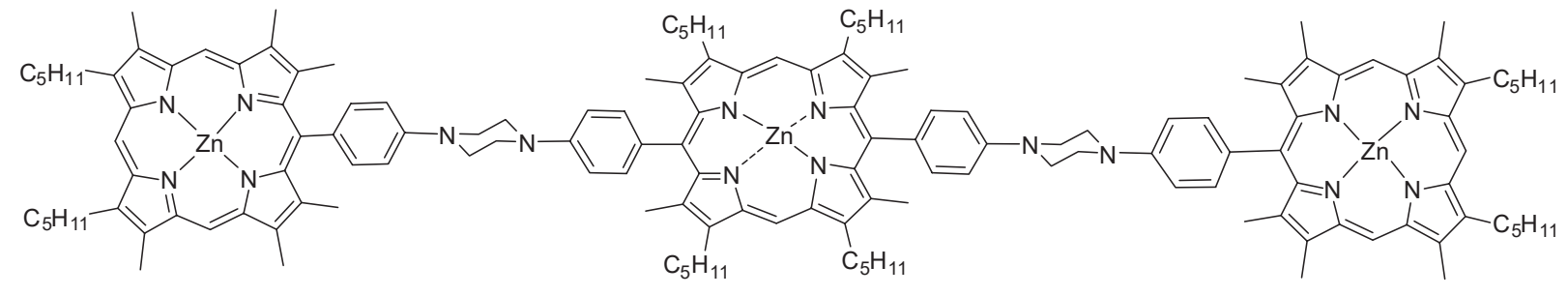

$56,75 \%$

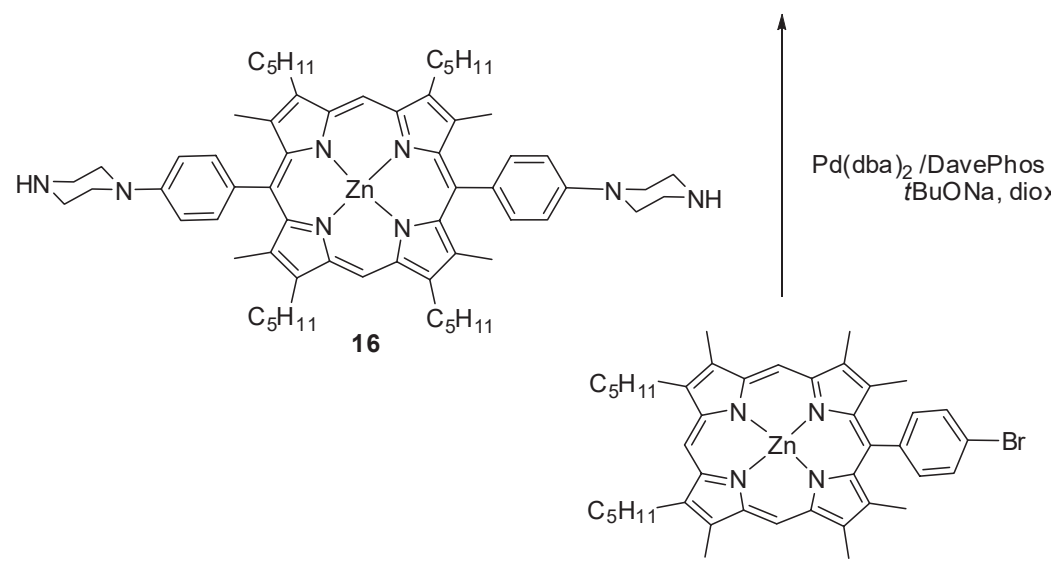

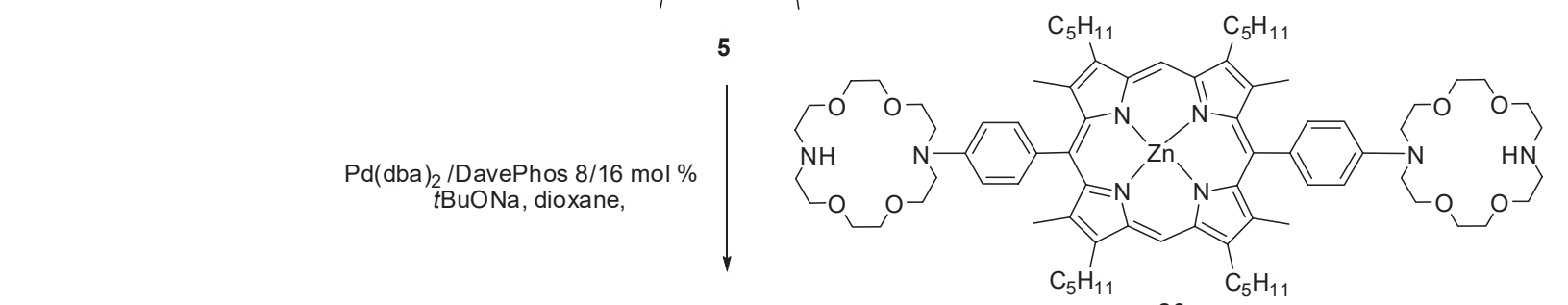

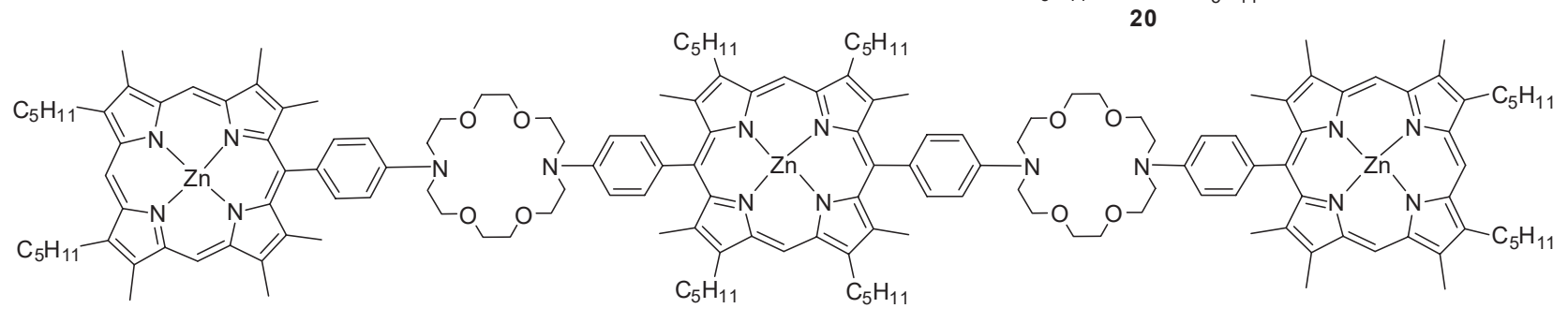

$\mathbf{5 7}, 27 \%$

Scheme 8 .

as colorimetric and fluorimetric chemosensors for metal cations. Diazatrioxamacrocycle 69 based on 3,3'-disubstituted biphenyl was synthesized according to a previously described method by $\mathrm{Pd}(0)$-catalyzed macrocyclization reaction of 3,3'-dibromobiphenyl with trioxadiamine, ${ }^{[56]}$ and macrocycle $\mathbf{7 0}$ comprising 2,7-disubstituted naphthalene fragment was obtained by the catalytic amination of 2,7-dibromonaphthalene. ${ }^{[57]}$ These macrocycles were introduced in the palladium-catalyzed arylation with 2 equiv. of $\mathrm{Zn}(\mathrm{II})$ porphyrinate $\mathbf{5}$ in the presence of $\mathrm{Pd}(\mathrm{dba})_{2} /$ DavePhos catalytic system, and the target bisporphyrin derivatives 71 and 72 were isolated in 27 and $18 \%$ yields, respectively (Scheme 13). Our investigations of UV-vis and fluorescence spectra of these compounds in the presence of 18 metal cations revealed that compound $\mathbf{7 1}$ could be used as fluorimetric molecular probe for $\mathrm{Al}(\mathrm{III})$ and $\mathrm{Cu}$ (II) cations as these metals totally quenched the emission, while trismacrocycle 72 would serve as a perspective fluorimetric chemosensor for $\mathrm{Cu}$ (II) cations as this metal selectively quenched emission and other cations did not interfere.

Macrobicycles 73-75 which differ by the size of the central diazacrown ether moiety, nature of the trioxadiamine chain and substitution pattern in aminobenzyl spacers were synthesized via $\mathrm{Pd}(0)$-catalyzed macrocyclization reactions using known procedures, ${ }^{[58]}$ and they were introduced in the catalytic diarylation reactions with 2 equiv. of $\mathrm{Zn}$ (II) pophyrinate 5 (Scheme 14). The yields of the target tetramacrocyclic compounds $\mathbf{7 6 - 7 8}$ with two porphyrin units ranged from 11 to $23 \%$ and substantial steric hindrances in the macrobicycles made this reaction enough difficult. Only Pd(dba) ${ }_{2} /$ DavePhos catalytic system was active in this case. These compounds were also tested as possible optical detectors of metal cations and tetramacrocycle 77 proved to be a perspective fluorescent chemosensor for $\mathrm{Cu}$ (II) cations as this metal selectively and fully quenched the emission without interference of other cations. 


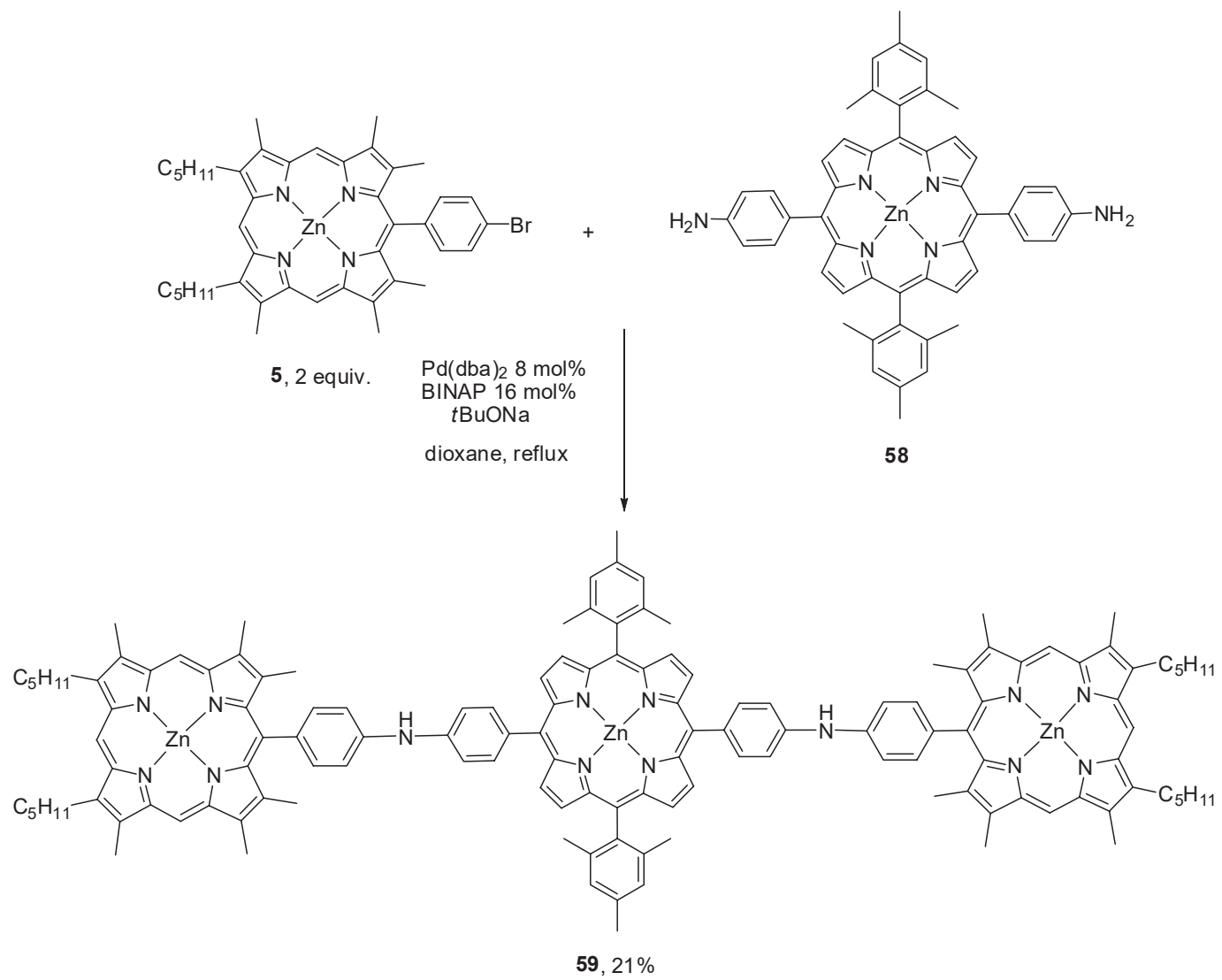

Scheme 9.

\section{Conclusions}

We demonstrated the possibilities to use palladium and copper-catalyzed amination of halogenophenyl porphyrins for the synthesis of different derivatives of monoporphyrin compounds, including the synthesis of the products of mono-, di-, and tetraamination. This approach was used for the introduction of aza- and diazacrown ethers in the porphyrin core thus giving rise to polymacrocyclic compounds. $\operatorname{Pd}(0)$-Catalyzed amination reactions were successfully employed for the synthesis of porphyrin dyads and triads, as were also $\mathrm{Cu}$-catalyzed 1,3-dipolar cycloaddition reactions which opened a way to porphyrin triads of various architectures. $\operatorname{Pd}(0)$-Catalyzed amination of bromophenyl substituted zinc porphyrinate with nitrogen- and oxygen-containing macrocycles and macrobicycles afforded tris- and tetramacrocyclic compounds which were found useful for creating fluorescent chemosensors for metal cations.

Acknowledgements. This work was financially supported by the RSF grant 14-23-00186.

\section{References}

1. Beletskaya I.P., Tyurin V.S., Uglov A., Stern C., Guilard R. Survey of Synthetic Routes for Synthesis and Substitution in Porphyrins. In: Handbook of Porphyrin Science, Vol. 23, 2012, p. 83.
2. Chan K.S., Zhou X., Luo B.S., Mak T.C. W. J. Chem. Soc Chem. Commun. 1994, 271.

3. Chan K.S., Zhou X.A., Au M.T., Tam C.Y. Tetrahedron 1995, 51,3129 .

4. Hyslop A.G., Kellett M.A., Iovine P.V., Therien M.J. J. Am. Chem. Soc. 1998, 120, 12676.

5. Ali H., van Lier J.E. Tetrahedron 1994, 50, 11933.

6. Shanmugathasan S., Johnson C.K., Edwards C., Matthews E.K., Dolphin D., Boyle R. W. J. Porphyrins Phthalocyanines 2000, 4, 228.

7. Chang J.C., Ma C.J., Lee G.H., Peng S.M., Yeh C.Y. Dalton Trans. 2005, 1504.

8. Gauler R., Risch N. Eur. J. Org. Chem. 1998, 1193.

9. Santos F.D., Cunha A.C., de Souza M.C.B.V., Tome A.C., Neves M.G.P.M.S., Ferreira V.F., Cavaleiro J.A.S. Tetrahedron Lett. 2008, 49, 7286.

10. Chen Y., Zhang X.P. J. Org. Chem. 2003, 68, 4432.

11. Takanami T., Hayashi M., Hino F., Suda K. Tetrahedron Lett. 2003, 44, 7353.

12. Khan M.M., Ali H., van Lier J.E. Tetrahedron Lett. 2001, 42, 1615.

13. Gao G.-Y., Chen Y., Zhang X.P. J. Org. Chem. 2003, $68,6215$.

14. Takanami T., Hayashi M., Hino F., Suda K. Tetrahedron Lett. 2003, 44, 7353.

15. Gao G.-Y., Chen Y., Zhang X.P. Org. Lett. 2004, 6, 1837.

16. Gao G.-Y., Ruppel J.V., Allen B., Chen Y., Zhang X.P. J. Org. Chem. 2007, 72, 9060.

17. Gao G.-Y., Colvin A.J., Chen Y., Zhang X.P. Org. Lett. 2003, 5 , 3261.

18. Gao G.-Y., Ruppel J.V., Fields K.B., Xu X., Chen Y., Zhang X.P. J. Org. Chem. 2008, 73, 4855.

19. Gao G.-Y., Colvin A.J., Chen Y., Zhang X.P. J. Org. Chem. 2004, 69, 8886. 


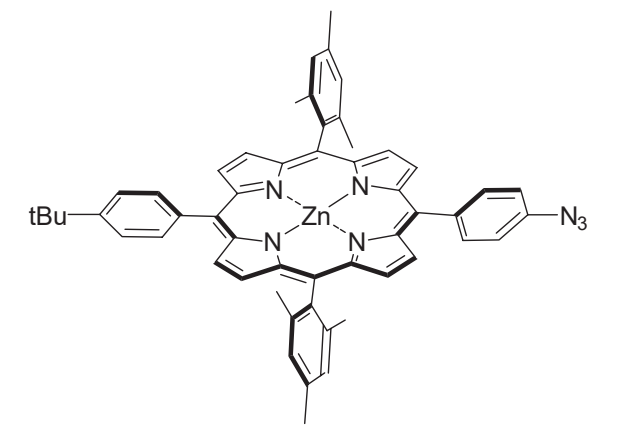

61, 2 equiv.

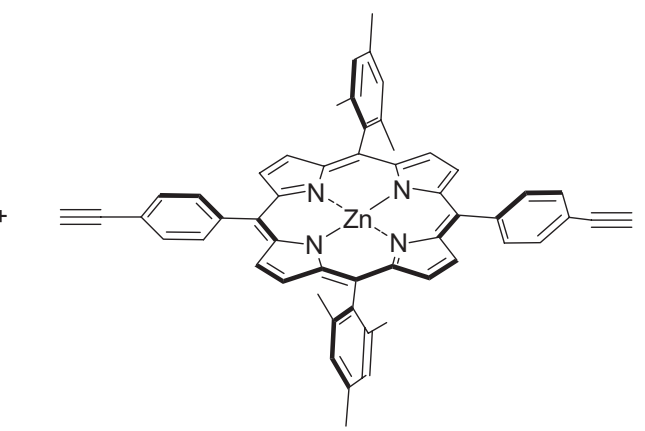

60

a) CuI/DIPEA, THF/MeCN, $60^{\circ} \mathrm{C}$

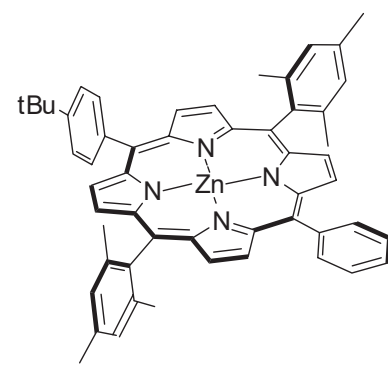

b) $\mathrm{CuSO} 4 \times 5 \mathrm{H}_{2} \mathrm{O}$, sodium ascorbate DMF, $100^{\circ} \mathrm{C}$

, $68 \%$ (method (a))

$60 \%$ (method (b))

Scheme 10.

20. Atefi F., McMurtrie J.C., Turner P., Duriska M., Arnold D.P. Inorg. Chem. 2006, 45, 6479.

21. Enakieva Y.Y., Bessmertnykh A.G., Gorbunova Y.G., Stern C., Rousselin Y., Tsivadze A.Y., Guilard R. Org. Lett. 2009, 11, 3842.

22. Hyslop A.G., Kellet M.A., Iovine P.M., Therien M.J. J. Am. Chem. Soc. 1998, 120, 12676.

23. Murata M., Watanabe T., Masuda Y. J. Org. Chem. 1997, 62, 6458.

24. Zhang C., Suslick K.S. J. Porphyrins Phthalocyanines 2005, 9, 659.

25. Deng Y.Q., Chang C.K., Nocera D.G. Angew. Chem. Int. Ed. 2000, 39, 1066.

26. Bringmann G., Gotz D.C.G., Gulder T.A.M., Gehrke T.H., Bruhn T., Kupfer T., Radacki K., Braunschweid H., Heckmann A., Lambert C. J. Am. Chem. Soc. 2008, 130, 17812.

27. Lu X.Q., Guo Y., Chen Q. Y. Synlett 2011, 77.

28. Cheng F.Y., Zhang S., Adronov A., Echegoyen L., Diederich F. Chem. Eur. J. 2006, 12, 6062.

29. Chung L.L., Chang C.J., Nocera D.G. J. Org. Chem. 2003, 68, 4075.

30. Yu L.H., Lindsey J.S. Tetrahedron 2001, 57, 9285

31. Sergeeva N.N., Scala A., Bakar M.A., O'Riordan G., O’Brien J., Grassi G., Senge M. O. J. Org. Chem. 2009, 74, 7140.

32. Frampton M.J., Akdas H., Cowley A.R., Rogers J.E., Slagle J.E., Fleitz P.A., Drobizhev M., Rebane A., Anderson H.L. Org. Lett. 2005, 7, 5365.

33. Odobel F., Suzenet F., Blart E., Quintard J.P. Org. Lett. 2000 , $2,131$.

34. Odobel F., Suresh S., Blart E., Nicolas Y., Quintard J.P., Janvier P., Le Questel J.Y., Illien B., Rondeau D., Richomme P., Haupl T., Wallin S., Hammarstorm L. Chem. Eur. J. 2002, 8, 3027.
35. Fazekas M., Pintea M., Senge M.O., Zawadzka M. Tetrahedron Lett. 2008, 49, 2236.

36. Esdaile L.J., Senge M.O., Arnold D.P. Chem. Commun. 2006, 4192.

37. Severac M., Le Pleux L., Scarpaci A., Blart E., Odobel F. Tetrahedron Lett. 2007, 48, 6518.

38. Sol V., Chaleix V., Granet R., Krausz P. Tetrahedron 2008, 64, 364.

39. Locos O.B., Arnold D.P. Org. Biomol. Chem. 2006, 4, 902.

40. Song J., Jang S.Y., Yamaguchi S., Sankar J., Hiroto S., Aratani N., Shin J.Y., Easwaramoorthi S., Kim K.S., Kim D., Shinokubo H., Osuka T. Angew. Chem. Int. Ed. 2008, 47, 6004.

41. van Gerven P.C.M., Elemans J.A.A.W., Gerritsen J.W., Speller S., Nolte R. J.M., Rowan A.E. Chem. Commun. 2005, 3535.

42. Artamkina G.A., Sazonov P.K., Shtern M.M., Grishina G.V., Veselov I.S., Semeikin A.S., Syrbu S.A., Koifman O.I., Beletskaya I.P. Synlett 2008, 45.

43. Artamkina G.A., Sazonov P.K., Shtern M.M., Grishina G.V., Veselov I.S., Semeikin A.S., Syrbu S.A., Koifman O.I., Beletskaya I.P. Russ. J. Org. Chem. 2008, 44, 421.

44. Mikhalitsyna E.A., Tyurin V.S., Khrustalev V.N., Lonin I.S., Beletskaya I.P. Dalton Trans. 2014, 43, 3563.

45. Mikhalitsyna E.A., Tyurin V.S., Zamilatskov I.A., Khrustalev V.N., Beletskaya I.P. Dalton Trans. 2012, 41, 7624.

46. Averin A.D., Shukhaev A.V., Buryak A.K., Denat F., Guilard R., Beletskaya I.P. Macroheterocycles 2009, 2, 281.

47. Kobelev S.M., Averin A.D., Buryak A.K., Denat F., Guilard R., Beletskaya I.P. Macroheterocycles 2014, 7, 28.

48. Ranyuk E.R., Filatov M.A., Averin A.D., Cheprakov A.V., Beletskaya I.P. Synthesis 2012, 44, 393.

49. Yakushev A.A., Averin A.D., Maloshitskaya O.A., Syrbu S.A., Koifman O.I., Beletskaya I.P. Macroheterocycles 2016, 9, 65. 


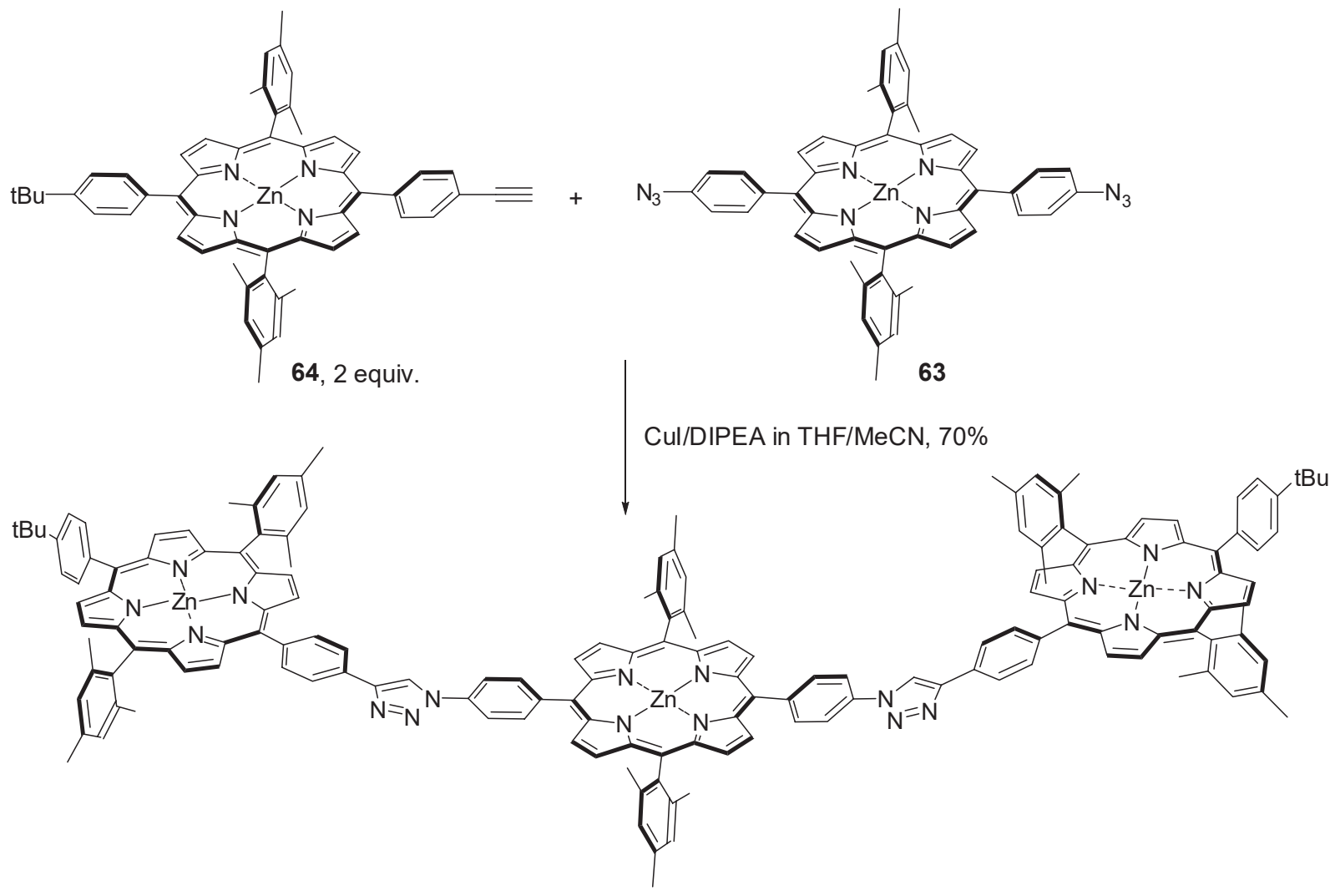

65, $70 \%$

Scheme 11.
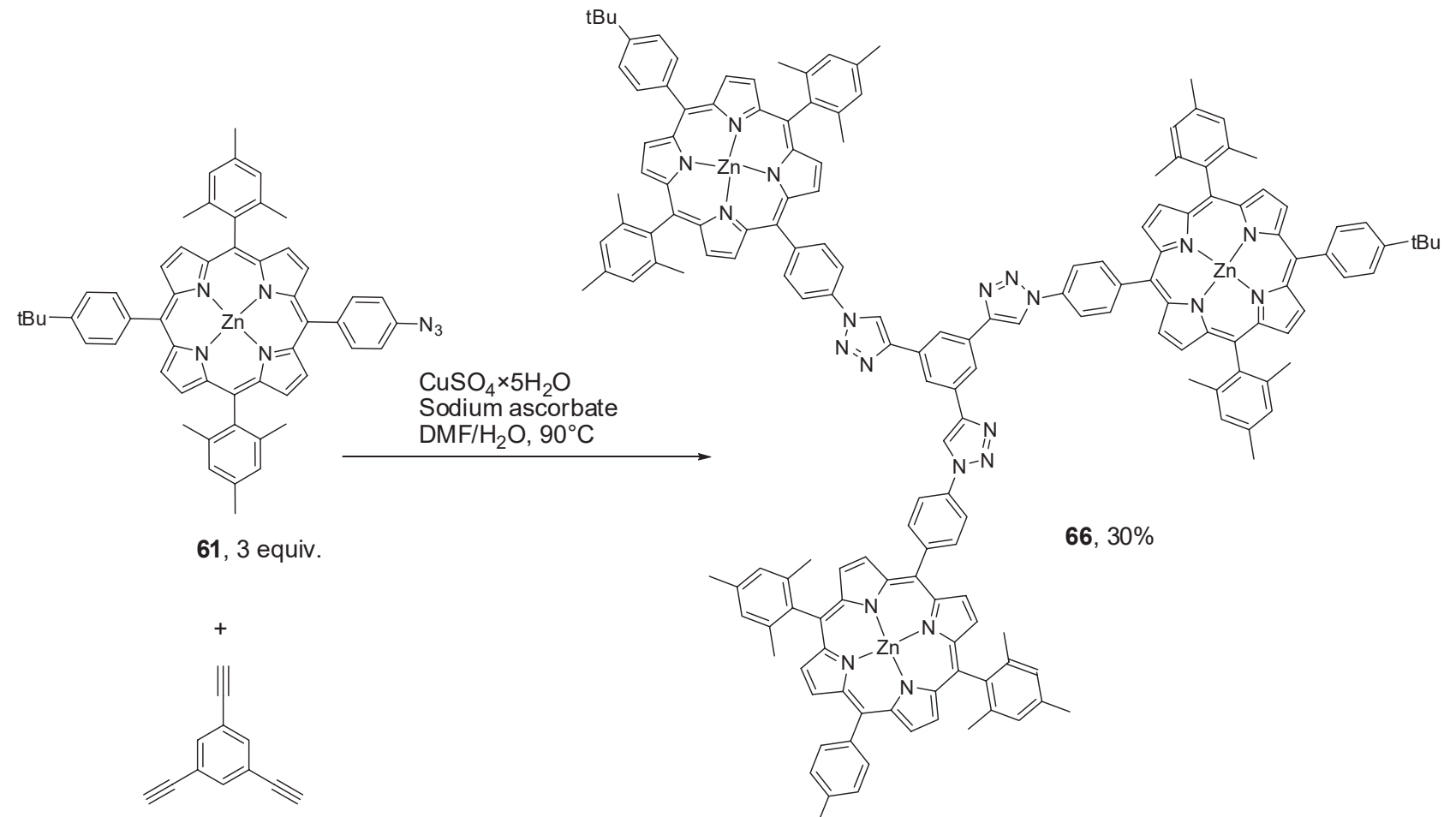

Sodium ascorbate $\mathrm{DMF} / \mathrm{H}_{2} \mathrm{O}, 90^{\circ} \mathrm{C}$

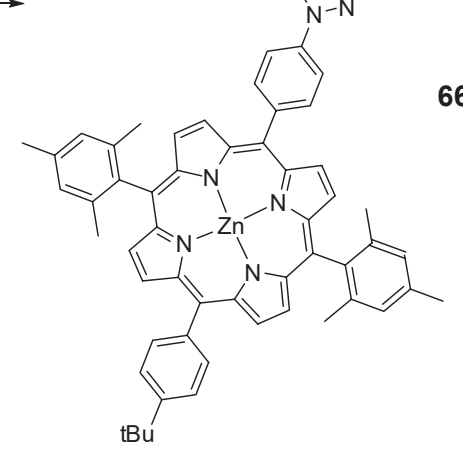

Scheme 12. 
<smiles></smiles>

67

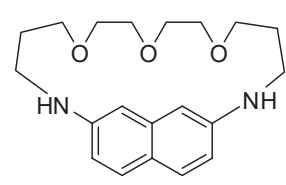

68

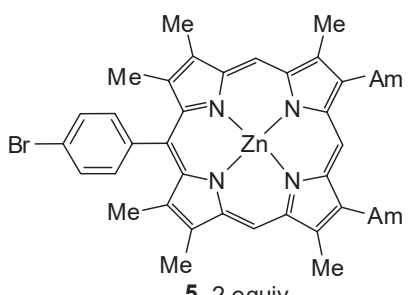

$\mathrm{Pd}(\mathrm{dba})_{2} /$ DavePhos tBuONa, dioxane
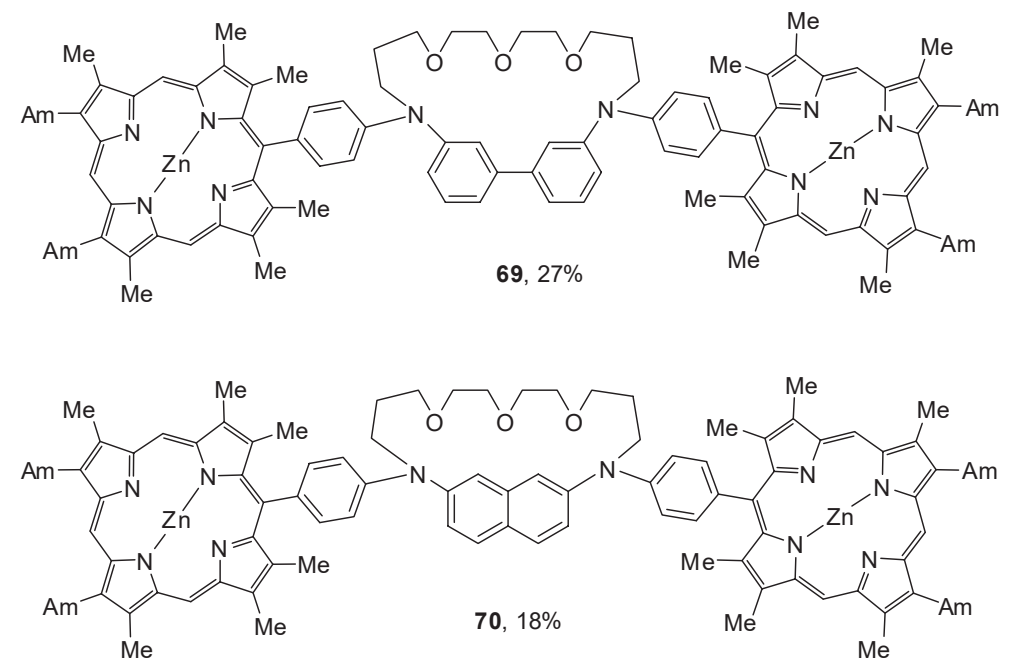

Scheme 13.
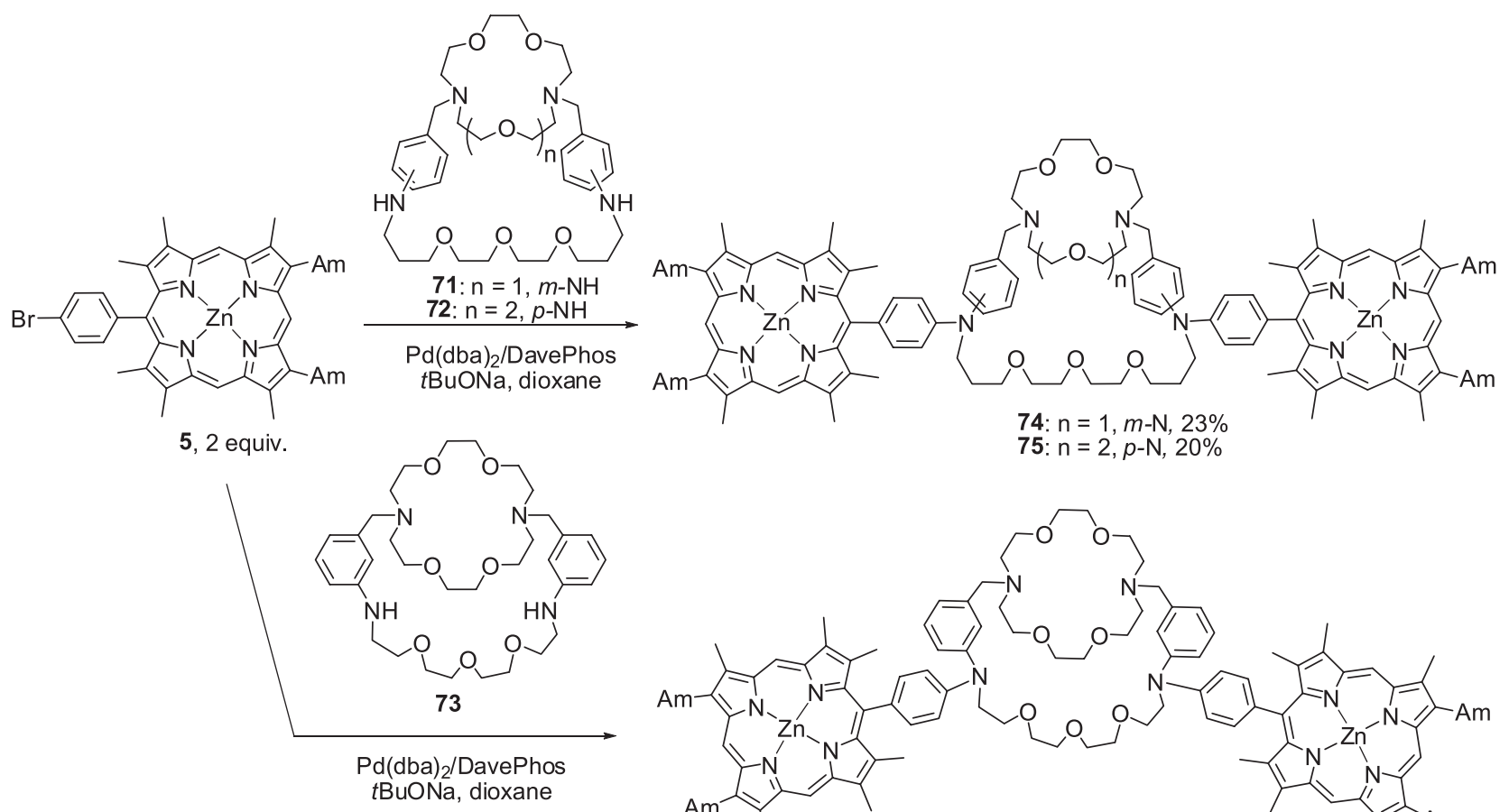

$74: \mathrm{n}=1, m-\mathrm{N}, 23 \%$
75: $\mathrm{n}=2, p-\mathrm{N}, 20 \%$

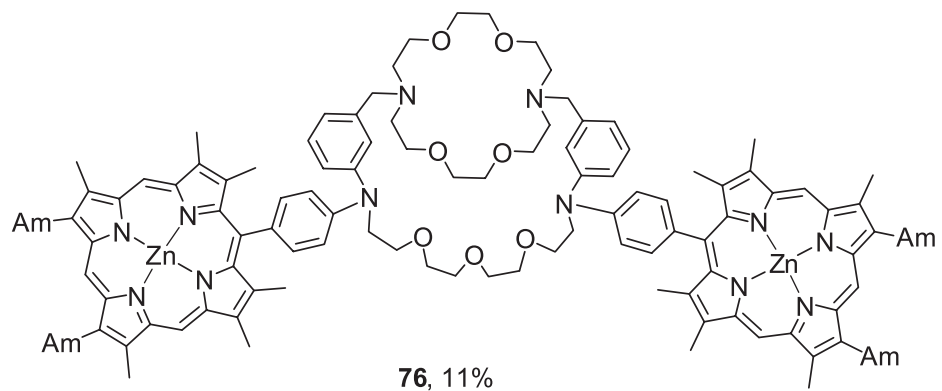

Scheme 14.

50. Yakushev A.A., Averin A.D., Anokhin M.V., Maloshitskaya O.A., Lamaty F., Beletskaya I.P. Macroheterocycles 2014, 7, 358.

51. Yakushev A.A., Averin A.D., Maloshitskaya O.A., Syrbu S.A., Koifman O.I., Beletskaya I.P. Mendeleev Commun. 2016, 26, 199.

52. Mikhalitsyna E.A., Tyurin V.S., Beletskaya I.P. J. Porphyrins Phthalocyanines 2015, 19, 874.

53. Tyurin V.S., Mikhalitsyna E.A., Semeikin A.S., Beletskaya I.P. Macroheterocycles 2015, 8, 358 .
54. Polevaya Y.P., Tyurin V.S., Beletskaya I.P. J. Porphyrins Phthalocyanines 2014, 18, 20.

55. Yaschuk Y.P., Tyurin V.S., Beletskaya I.P. Macroheterocycles 2012, 5, 302.

56. Averin A.D., Uglov A.N., Buryak A.K., Beletskaya I.P. Mendeleev Commun. 2010, $20,1$.

57. Averin A.D., Uglov A.N., Beletskaya I.P. Chem. Lett. 2008, 37 , 1074.

58. Yakushev A.A., Chernichenko N.M., Anokhin M.V., Averin A.D., Buryak A.K., Denat F., Beletskaya I.P. Molecules 2014, 19, 940 . 